medRxiv preprint doi: https://doi.org/10.1101/2020.09.27.20202515; this version posted September $28,2020$. The copyright holder for this preprint (which was not certified by peer review) is the author/funder, who has granted medRxiv a license to display the preprint in It is made available under a CC-BY-ND 4.0 International license.

\title{
Impact of $B R C A$ mutation status on tumor infiltrating lymphocytes (TILs), response to treatment, and prognosis in breast cancer patients treated with neoadjuvant chemotherapy.
}

Beatriz Grandal $^{l, 10 *}$, Clémence Evrevin ${ }^{l *}$, Enora Laas $^{l}$, Isabelle $\operatorname{Jardin}^{l}$, Sonia Rozette ${ }^{l}$, Lucie Laot ${ }^{l}$, Elise $\operatorname{Dumas}^{10}$, Florence Coussy ${ }^{2}$, Jean-Yves Pierga ${ }^{2}$, Etienne Brain ${ }^{3}$, Claire Saule ${ }^{4}$, Dominique Stoppa-Lyonnet ${ }^{4}$, Sophie Frank ${ }^{4}$, Claire Sénéchal ${ }^{5}$, Marick Lae ${ }^{6,7}$, Diane De Croze $^{6}$, Guillaume Bataillon ${ }^{8}$, Julien Guerin ${ }^{9}$, Fabien Reyal $^{1,10^{* * *}}$, Anne-Sophie Hamy ${ }^{10 * *}$

* Beatriz Grandal and Clémence Evrevin / ** Fabien Reyal and Anne-Sophie Hamy contributed equally to this work.

\section{Affiliations:}

1. Department of Surgery, Institut Curie, 26 rue d'Ulm, 75005 Paris, France

2. Department of Oncology, Institut Curie, 26 rue d'Ulm, 75005 Paris, France

3. Department of Oncology, Centre René Huguenin - Institut Curie, 35 rue Dailly, 92210 St Cloud, France

4. Department of Genetics, Institut Curie, 26 rue d'Ulm, 75005 Paris, France INSERM U830, Institut Curie Paris, Paris, France.

5. Department of Genetics, Institut Bergonié, 229 Cours de l'Argonne, 33000 Bordeaux, France

6. Department of Pathology, Centre René Huguenin - Institut Curie, 35 rue Dailly, 92210 St Cloud, France

7. Department of Pathology, Centre Henri Becquerel, INSERM U1245, uniRouen, University of Normandie, Rouen, France

8. Department of Pathology, Institut Curie, 26 rue d'Ulm, 75005 Paris, France

9. Data Office, Institut Curie, 25 rue d'Ulm, 75005 Paris, France

10. Residual Tumor \& Response to Treatment Laboratory, RT2Lab, translational Research Department, INSERM, U932 Immunity and Cancer, Institut Curie, 26 rue d'Ulm, Paris, France 
medRxiv preprint doi: https://doi.org/10.1101/2020.09.27.20202515; this version posted September 28, 2020. The copyright holder for this preprint (which was not certified by peer review) is the author/funder, who has granted medRxiv a license to display the preprint in It is made available under a CC-BY-ND 4.0 International license .

\section{Running title:}

Impact of $B R C A$ mutation status on TILs, pCR and survival in breast cancer patients treated with neoadjuvant chemotherapy.

\section{Keywords:}

BRCA, TILs, pCR, NAC, immunotherapy

\section{Financial Support:}

B.G.R. was supported by Alfonso Martin Escudero Foundation research grant.

\section{Corresponding author:}

Pr. Fabien REYAL

Institut Curie, 26 rue d'Ulm, 75005 Paris, France

+33 144324660/ Fax +33 153104037

fabien.reyal@curie.fr

\section{Conflict of interest}

The authors declare no potential conflicts of interest.

\section{Others}

Word count: 3152

Total number of figures: 4

Total number tables: 2 
medRxiv preprint doi: https://doi.org/10.1101/2020.09.27.20202515; this version posted September 28, 2020. The copyright holder for this preprint (which was not certified by peer review) is the author/funder, who has granted medRxiv a license to display the preprint in It is made available under a CC-BY-ND 4.0 International license .

\section{Translational relevance}

1 High lymphocytic infiltration (TILs) seem to reflect favorable host antitumor immune

2 responses. In breast cancer, the variation of TILs before and after neoadjuvant chemotherapy 3 (NAC) according to BRCA status has been poorly described. Little data is available on their

4 value after treatment. We investigated TIL levels before and after NAC and response to

5 treatment in 267 paired biopsy and surgical specimens.

6 In our study, luminal BCs were associated with pathologic complete response (pCR) and

7 higher TIL levels after chemotherapy completion in patients with BRCA pathogenic 8 mutations. Our data supports that (i) NAC should be reconsidered in luminal BCs with $B R C A$

9 pathogenic mutation, (ii) TILs could be a biomarker for response to immune checkpoint

10 blockade in luminal BCs with $B R C A$ pathogenic variant who did not achieve a pCR and (iii)

11 exploiting the antitumor immune response in luminal BCs could be an area of active research. 
medRxiv preprint doi: https://doi.org/10.1101/2020.09.27.20202515; this version posted September 28, 2020. The copyright holder for this preprint (which was not certified by peer review) is the author/funder, who has granted medRxiv a license to display the preprint in It is made available under a CC-BY-ND 4.0 International license .

\section{Abstract:}

2 Introduction: Five to $10 \%$ of breast cancers (BCs) occur in a genetic predisposition context

3 (mainly BRCA pathogenic variant). Nevertheless, little is known about immune tumor

4 infiltration, response to neoadjuvant chemotherapy (NAC), pathologic complete response

5 (pCR) and adverse events according to $B R C A$ status.

6 Material and methods: Out of 1199 invasive BC patients treated with NAC between 2002 and

7 2012, we identified 267 patients tested for a germline $B R C A$ pathogenic variant. We evaluated

8 pre-NAC and post-NAC immune infiltration (TILs). Response to chemotherapy was assessed

9 by pCR rates. Association of clinical and pathological factors with TILs, pCR and survival

10 was assessed by univariate and multivariate analyses.

11 Results: Among 1199 BC patients: 46 were BRCA-deficient and 221 BRCA-proficient or wild 12 type (WT). At NAC completion, pCR was observed in 84/266 (31\%) patients and pCR rates 13 were significantly higher in $B R C A$-deficient $\mathrm{BC}(p=0.001)$, and this association remained 14 statistically significant only in the luminal BC subtype $(p=0.006)$. The interaction test 15 between BC subtype and $B R C A$ status was nearly significant $\left(P_{\text {interaction }}=0.056\right)$. Pre and post16 NAC TILs were not significantly different between BRCA-deficient and BRCA-proficient 17 carriers; however, in the luminal BC group, post-NAC TILs were significantly higher in 18 BRCA-deficient BC. Survival analysis were not different between $B R C A$-carriers and non19 carriers.

20 Conclusion: BRCA mutation status is associated with higher pCR rates and post-NAC TILs in 21 patients with luminal BC. BRCA-carriers with luminal BCs may represent a subset of patients 22 deriving higher benefit from NAC. Second line therapies, including immunotherapy after 23 NAC, could be of interest in non-responders to NAC. 
medRxiv preprint doi: https://doi.org/10.1101/2020.09.27.20202515; this version posted September $28,2020$. The copyright holder for this preprint (which was not certified by peer review) is the author/funder, who has granted medRxiv a license to display the preprint in

It is made available under a CC-BY-ND 4.0 International license .

\section{Introduction}

2 Neoadjuvant or pre-operative chemotherapy (NAC) is classically administered to patients

3 with inflammatory or locally advanced breast cancer (BC). Beyond increasing breast-

4 conserving surgery rates (1), it also serves as an in vivo chemosensitivity test and the analysis

5 of residual tumor burden may help understanding treatment resistance mechanisms (2). In

6 addition, it helps refining the prognosis of patients after NAC, as pathological complete

7 response (pCR) after NAC is associated with a better long term survival $(1,3)$.

8 Nearly $5 \%$ of breast cancers occur in a context of genetic predisposition, mostly represented

9 by monoallelic pathogenic variants of BRCA1, BRCA2 or PALB2 genes (4). Patients with

10 loss-of-function of the BRCA1 or 2 proteins have a higher cumulated breast cancer risk, with

11 a cumulated life time risk at eighty years old of $72 \%(B R C A 1)$ and $69 \%(B R C A 2)(5)$. The

12 peak incidence for BRCAl mutation carriers occurs between 41 and 50 years old (28.3 per

131000 person-years), whereas it occurs ten years later for $B R C A 2$ mutation carriers (30.6 per

141000 person-years between 51 and 60) (5). BRCA1 and BRCA2 are tumor-suppressor genes

15 that code for proteins involved in homologous recombination (HR) repair. HR deficiency

16 (HRD) occurs when the second allele is inactivated by allelic deletion (often detected by

$17 \mathrm{LOH}$ ), genic alteration or promoter methylation (for BRCA1 only). Biallelic BRCA1/2

18 inactivation results in genomic instability and theoretically increases the somatic mutational

$19 \operatorname{load}(6)$.

20 Tumors associated with germline or somatic BRCA1/2 pathogenic mutations display

21 different patterns when compared with sporadic BCs. Cancers occurring among BRCA1

22 carriers are more frequently classified as medullary (7), whereas histological subtypes among

23 BRCA2 carriers tend to be more heterogeneous (8). In addition, BRCA1 carriers are more

24 frequently ER-negative, PR-negative and lack HER2 amplification (i.e. display a triple 
medRxiv preprint doi: https://doi.org/10.1101/2020.09.27.20202515; this version posted September 28, 2020. The copyright holder for this preprint (which was not certified by peer review) is the author/funder, who has granted medRxiv a license to display the preprint in It is made available under a CC-BY-ND 4.0 International license .

1 negative (TNBCs) phenotype (9))- whereas in BRCA2 carriers, a similar prevalence of ER-

2 positive tumors has been described when compared with sporadic controls (10-13).

3 Most of patients with TNBCs receive chemotherapy $(14,15)$. Due to the alteration of BRCA1

4 and BRCA2 proteins in tumor cells, BRCA-mutated cells are unable to properly repair double-

5 strand breaks, classically induced by DNA-alkylating agents (16). Hence, BRCA deficiency

6 has sometimes been associated with a higher sensitivity to platinum agents when compared to

7 other types of neoadjuvant chemotherapy regimens (17-19). However, the effectiveness of

8 standard NAC in all $\mathrm{BC}$ subtypes associated with $B R C A$ pathogenic variants compared to

9 controls has been poorly explored so far.

10 The role of tumor infiltrating lymphocytes (TILs) in BC has been extensively studied over

11 the last decade. High levels of TILs before NAC are associated with higher pCR rates and 12 better survival, especially for TNBC and HER2-positive BCs (20,21). However, despite a 13 growing interest in the field of immunity and oncology, characterization and quantification of 14 TILs across all BC subtypes according to $B R C A$ status has not been extensively described. 15 Similarly, no study has evaluated so far, the evolution of immune infiltration after NAC 16 according to $B R C A$ status.

17 The objective of the current study is to determine if pre and post-NAC TILs, chemosensitivity 18 and prognosis differ according to $B R C A$ status in a cohort of BC patients treated with NAC. 
medRxiv preprint doi: https://doi.org/10.1101/2020.09.27.20202515; this version posted September 28, 2020. The copyright holder for this preprint (which was not certified by peer review) is the author/funder, who has granted medRxiv a license to display the preprint in It is made available under a CC-BY-ND 4.0 International license.

\section{$1 \quad$ Material and methods:}

\section{$2 \quad$ Patients and Tumors}

3 The study was performed on a retrospective institutional cohort of 1199 female patients with

4 T1-T3NxM0 invasive BC (NEOREP Cohort, CNIL declaration number 1547270) treated with

$5 \quad$ NAC at Institute Curie (Paris and Saint-Cloud) between 2002 and 2012. The cohort included

6 unifocal, unilateral, non-recurrent, non-metastatic tumors, excluding T4 tumors

7 (inflammatory, chest wall or skin invasion). Approved by the Breast Cancer Study Group of

8 Institute Curie, the study was conducted according to institutional and ethical rules

9 concerning research on tissue specimens and patients. Informed consent from patients was not

10 required.

11 Information on family history, clinical characteristics (age; menopausal status; body mass 12 index) and tumor characteristics (clinical tumor stage and grade; histology; clinical nodal 13 status; ER, PR and HER2 status; BC subtype; mitotic index; Ki67) were retrieved from 14 electronic medical records. All the patients received NAC, and additional treatments were 15 decided according to national guidelines (see Supplementary material).

Tumors samples

In accordance with French national guidelines (22), cases were considered estrogen receptor

19 (ER)-positive or progesterone receptor (PR)-positive if at least $10 \%$ of tumor cells expressed 20 estrogen and/or progesterone receptors (ER/PR), and endocrine therapy was prescribed when 21 this threshold was exceeded. HER2 negative status was defined as 0 or $1+$ on 22 immunohistochemistry (IHC) stained tissue section. IHC $2+$ scores were subsequently 23 analyzed by fluorescence in situ hybridization (FISH) to confirm HER2 positivity. 
medRxiv preprint doi: https://doi.org/10.1101/2020.09.27.20202515; this version posted September 28, 2020. The copyright holder for this preprint (which was not certified by peer review) is the author/funder, who has granted medRxiv a license to display the preprint in It is made available under a CC-BY-ND 4.0 International license.

1 Pathological BC were classified into subtypes (TNBC, HER2-positive, and luminal HER2-

2 negative [referred to hereafter as "luminal"]) (see Supplementary material).

4 TIL levels, pathological complete response and pathological review:

5 TIL levels were evaluated retrospectively for research purposes, by two pathologists (ML and

6 DdC) specialized in breast cancer. TIL levels were assessed on formalin-fixed paraffin7 embedded (FFPE) tumor tissue samples from pretreatment core needle biopsies and the 8 corresponding post-NAC surgical specimens, according to the recommendations of the 9 international TILs Working Group before (23) and after NAC (24). TILs were defined as the 10 presence of a mononuclear cell infiltrate (including lymphocytes and plasma cells, excluding 11 polymorphonuclear leukocytes). TILs in direct contact with tumor cells were counted as intra12 tumoral TILs (IT TILs) and those in the peri-tumoral areas as stromal TILs (str TILs). They 13 were evaluated both in the stroma and within tumor scar border, after excluding areas around 14 ductal carcinoma in situ, tumor zones with necrosis and artifacts, and were scored 15 continuously as the average percentage of stroma area occupied by mononuclear cells.

16 We defined pathological complete response ( $\mathrm{pCR}$ ) as the absence of invasive residual tumor 17 from both the breast and axillary nodes (ypT0/is N0).

BRCA status

20 Genetic counseling was offered based on individual or family criteria (see Supplemental 21 material). When constitutional genetic analysis of $B R C A 1$ and $B R C A 2$ genes were required, 22 Denaturing High Performance Liquid Chromatography (DHPLC) and Sanger sequencing 23 were performed to search for point alterations, and Quantitative Multiplex Polymerase Chain 24 Reaction of Short Fluorescent (QMPSF) to research large gene rearrangements between 2002 
medRxiv preprint doi: https://doi.org/10.1101/2020.09.27.20202515; this version posted September 28, 2020. The copyright holder for this preprint (which was not certified by peer review) is the author/funder, who has granted medRxiv a license to display the preprint in It is made available under a CC-BY-ND 4.0 International license .

1 and 2012. In case of previously known pathogenic familial variants, targeted tests were 2 performed.

\section{$4 \quad$ Survival endpoints}

5 Relapse-free survival (RFS) was defined as the time from surgery to death, loco-regional

6 recurrence or distant recurrence, whichever occurred first. Overall survival (OS) was defined 7 as the time from surgery to death. For patients for whom none of these events were recorded, data was censored at the time of last known contact. Survival cutoff date analysis was

$9 \quad$ February $1^{\text {st }}, 2019$.

11 Statistical analysis

12 Pre- and post-NAC TIL levels were analyzed as continuous variables. All analyses were 13 performed on the whole population and after stratification by $\mathrm{BC}$ subtype. To compare continuous variables among different groups, Wilcoxon-Mann-Whitney test was used for 15 groups including less than 30 patients and for variables displaying multimodal distributions; otherwise, student t-test was used. Association between categorical variables was assessed with chi-square test, or with the Fisher's exact test if at least one category included less than three patients. In boxplots, lower and upper bars represented the first and third quartile respectively, the medium bar was the median, and whiskers extended to 1.5 times the interquartile range. Factors predictive of $\mathrm{pCR}$ were introduced in a univariate logistic regression model. Covariates selected for multivariate analysis were those with a $p$-value no greater than 0.1 after univariate analysis. Survival probabilities were estimated by Kaplan-Meyer method, and survival curves were compared with log-rank tests. Hazard ratios (HR) and their 95\% confidence intervals (CI) were calculated with the Cox proportional hazard model. Analyses 
medRxiv preprint doi: https://doi.org/10.1101/2020.09.27.20202515; this version posted September 28,2020 . The copyright holder for this preprint (which was not certified by peer review) is the author/funder, who has granted medRxiv a license to display the preprint in

\section{Results}

\section{Study population and tumors characteristics}

3 The total number of patients included in the neoadjuvant cohort was 1199. Among the whole

4 population, germline $B R C A$ pathogenic variant status was available for 267 patients (22.3\%),

5 and was not obtained for 932 patients $(77.73 \%$, Supplementary Figs. S1). Median age of

6 cohort's population was 48 years old (range 24-80) and most patients $(n=747,62 \%)$ were

7 premenopausal. Median BMI index was 24.74 , and $25.8 \%$ had direct family history of breast

8 cancer. Patients repartition by subtype was as follows: luminal $(\mathrm{n}=518,44 \%)$, TNBC $(\mathrm{n}=376$,

$931 \%)$, HER2-positive $(\mathrm{n}=295,25 \%)$.

10 Patients with available $B R C A$ status were significantly different from patients with $B R C A$

11 status unknown. They were younger, had lower body mass index, were more likely to be

12 diagnosed with grade III, TNBC of no specific type (NST), and to receive standard

13 anthracyclines-taxanes containing regimens than patients not screened $(\mathrm{p}<0.001)$ (Table1,

\section{Supplementary Figs. S2).}

15 Among the 267 screened patients, the distribution of $B R C A$ status was as follows: $B R C A$ 16 proficient $\mathrm{n}=221(83 \%) ; B R C A$-deficient, $\mathrm{n}=46(17 \%)$ (BRCAl-deficient, $\mathrm{n}=31(67.39 \%)$; 17 BRCA2-deficient, $\mathrm{n}=14(30.43 \%)$ and $B R C A 1+2$-deficient, $\mathrm{n}=1(2.17 \%))$. Median age at 18 diagnosis for patient with available $B R C A$ mutation status was 40 years old (range 24-70) and 19 most patients $(\mathrm{n}=227,85 \%)$ were premenopausal. Patients repartition by subtype was as 20 follows: luminal $(\mathrm{n}=90,33.7 \%), \operatorname{TNBC}(\mathrm{n}=110,41.2 \%), \operatorname{HER} 2$-positive $(\mathrm{n}=67,25.1 \%)$

21 (Supplementary Table S1, Supplementary Fig. S2).

22 Carriers of a $B R C A$ pathogenic variant were more likely to have familial history of breast 23 cancer $(73.9 \%$ vs. $52.3 \%, \mathrm{p}=0.012)$, and to be diagnosed with TNBC $(58.7 \%$ vs $37.6 \%$; $=$ 
medRxiv preprint doi: https://doi.org/10.1101/2020.09.27.20202515; this version posted September 28, 2020. The copyright holder for this preprint (which was not certified by peer review) is the author/funder, who has granted medRxiv a license to display the preprint in It is made available under a CC-BY-ND 4.0 International license .

1 0.006) than BRCA-proficient patients (Table 1). No other pattern among age, body mass

2 index, histology, tumor size, nor proliferation indices (grade, mitotic index, KI67) was

3 significantly different according to $B R C A$ variant status. These results were substantially

4 similar after the subgroup analysis of BC subtype (Supplementary Table S2). 
medRxiv preprint doi: https://doi.org/10.1101/2020.09.27.20202515; this version posted September $28,2020$. The copyright holder for this preprint (which was not certified by peer review) is the author/funder, who has granted medRxiv a license to display the preprint in

It is made available under a CC-BY-ND 4.0 International license .

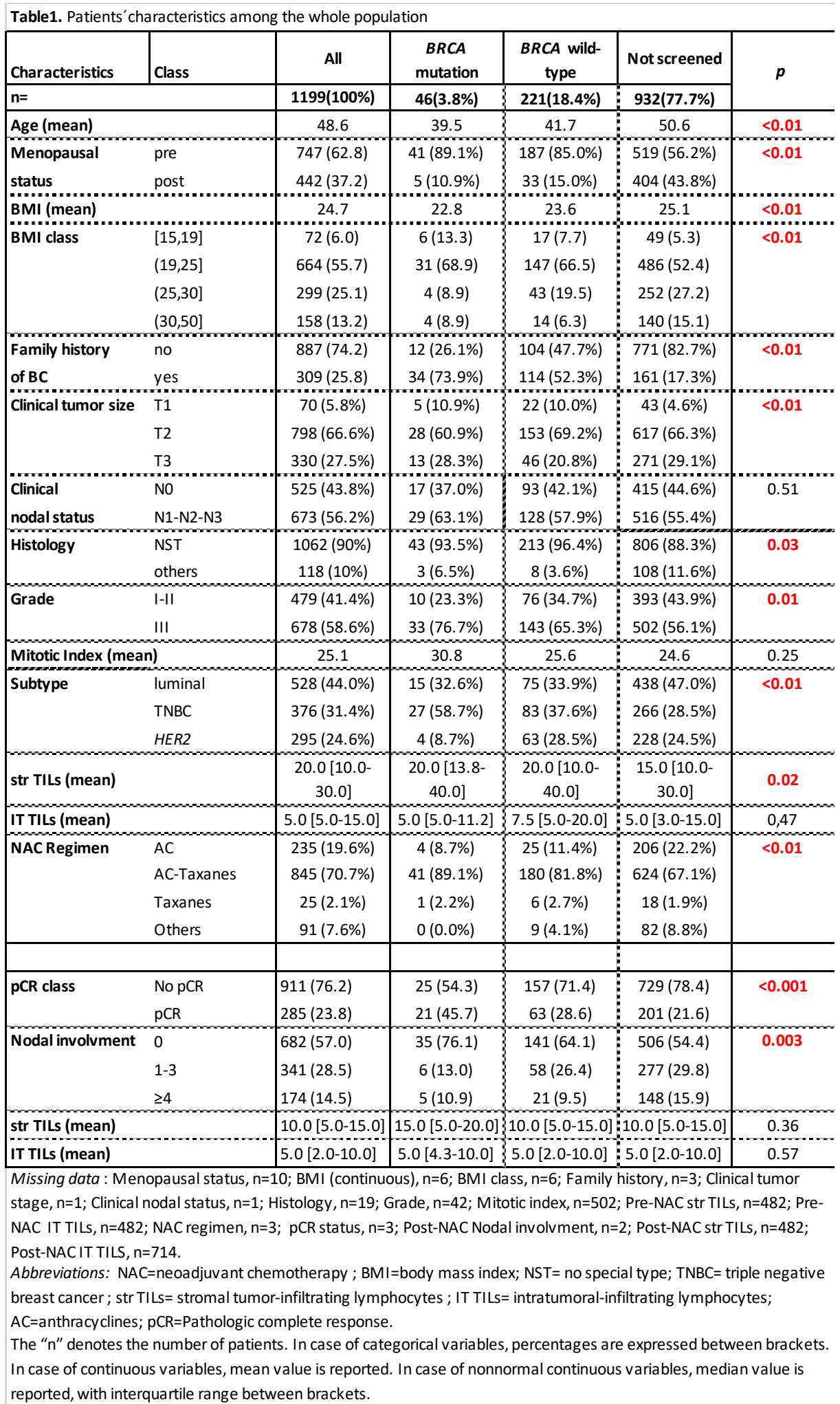

2 Baseline TILs were available for 192 out of 267 screened patients (72\%). Neither pre-NAC

3 str TIL levels (Figs 1A-D), nor IT TILs (Figs 1E-H) were significantly different by BRCA

4 status (Supplementary Table S1), nor in each BC subtype (Supplementary Table S2). 
medRxiv preprint doi: https://doi.org/10.1101/2020.09.27.20202515; this version posted September $28,2020$. The copyright holder for this preprint (which was not certified by peer review) is the author/funder, who has granted medRxiv a license to display the preprint in

It is made available under a CC-BY-ND 4.0 International license .

1 There was a strong, positive, linear relationship between stromal and intra-tumoral TILs

2 (Spearman correlation coefficient of $0.74, p<0.001$, Supplementary Fig. S3)

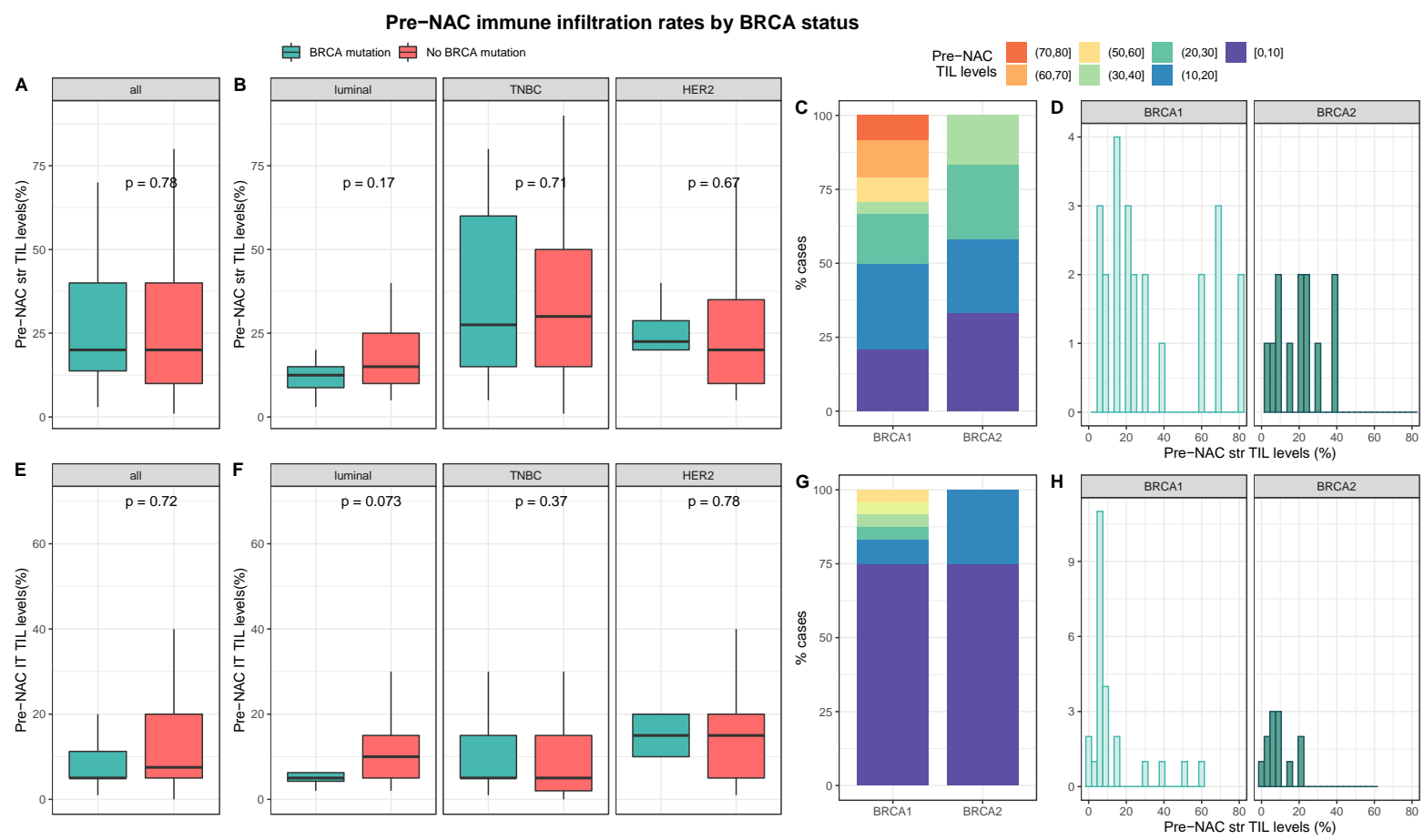

BC patients with pre-NAC str TLL levels available [n=192; BRCA1 (n=24), BRCA2 (n=12)] and IT TLL levels [n=192; BRCA1 (n=24), BRCA2 (n=12)

Figure 1. Associations between pre-NAC TILs and BRCA status in whole population, and by breast cancer subtype. Bottom and top bars of the boxplots represent the first and third quartiles, respectively, the medium bar is the median, and whiskers extend to 1.5 times the interquartile range. A, stromal lymphocytes among the whole population (All( $n=192), B R C A$ mutation $(n=36), B R C A$ wild-type( $n=156)$. B, stromal lymphocytes in each $B C$ subtype (Luminal $(n=52), B R C A$ mutation $(n=8), B R C A$ wild-type $(n=44)$; TNBC( $n=97), B R C A$ mutation( $(n=24)$, $B R C A$ wild-type $(\mathrm{n}=73)$; HER2( $\mathrm{n}=43), B R C A$ mutation $(\mathrm{n}=4), B R C A$ wild-type $(\mathrm{n}=39)$. C, percentage of tumor according to pre-NAC stromal lymphocytes levels binned by $10 \%$ increment in patients with $B R C A$-deficient $(B R C A 1(n=24), B R C A 2(n=12))$. $D$, distribution of pre-NAC stromal lymphocytes by gene mutations (histogram plot) in patients with $B R C A$-deficient $(B R C A 1(\mathrm{n}=24), B R C A 2(\mathrm{n}=12))$. $\mathrm{E}$, intratumoral lymphocytes among the whole population (All $(\mathrm{n}=192), B R C A$ mutation $(\mathrm{n}=36), B R C A$ wild-type( $\mathrm{n}=156))$. $F$, intratumoral lymphocytes in each $B C$ subtype (Luminal( $\mathrm{n}=52), B R C A$ mutation $(\mathrm{n}=8), B R C A$ wild-type $(\mathrm{n}=44)$; TNBC( $\mathrm{n}=97), B R C A$ mutation $(\mathrm{n}=24), B R C A$ wild-type $(\mathrm{n}=73)$; HER2 ( $\mathrm{n}=43), B R C A$ mutation( $(\mathrm{n}=4), B R C A$ wild-type $(\mathrm{n}=39))$. $\mathrm{G}$, Percentage of tumor according to pre-NAC intratumoral lymphocytes levels binned by $10 \%$ increment in patients with $B R C A$-deficient $(B R C A 1(n=24), B R C A 2(n=12))$. $\mathbf{H}$, distribution of pre-NAC intratumoral lymphocytes by gene mutations (histogram plot) in patients with $B R C A$-deficient $(B R C A 1(\mathrm{n}=24), B R C A 2(\mathrm{n}=12))$.

\section{Response to treatment and post-NAC immune infiltration}

\section{Response to treatment}

At NAC completion, pCR was observed in 84 out of $266(31 \%)$ patients and pCR rates were 
medRxiv preprint doi: https://doi.org/10.1101/2020.09.27.20202515; this version posted September 28, 2020. The copyright holder for this preprint (which was not certified by peer review) is the author/funder, who has granted medRxiv a license to display the preprint in It is made available under a CC-BY-ND 4.0 International license .

1 ], $p<0.001$; Supplementary Fig. S3) and in the TNBC subgroup (luminal: OR $=1.03$, CI95\%

$2[1-1.09$ ], $p=0.21$;NBC: OR $=1.03 ;$ CI95\% [ 1-1.04], $p=0.007$; HER2-positive: OR $=$

3 1.02, CI95\% [ 0.99-1.06], $p=0.23$; Supplementary Fig. S4).

4 pCR rates were significantly higher in patients with BRCA-deficient breast cancers (45.7\% 5 (21/46) versus $28 \%$ (63/221) in BRCA-proficient, $p<0.035$, Supplementary Table S1,

6 Figure 2). After the subgroup analysis of BC subtype, this was confirmed only in the luminal 7 BC subtype $(33.3 \%(5 / 15), p=0.006)$, but not in TNBC and HER2-positive BCs (48.1\%

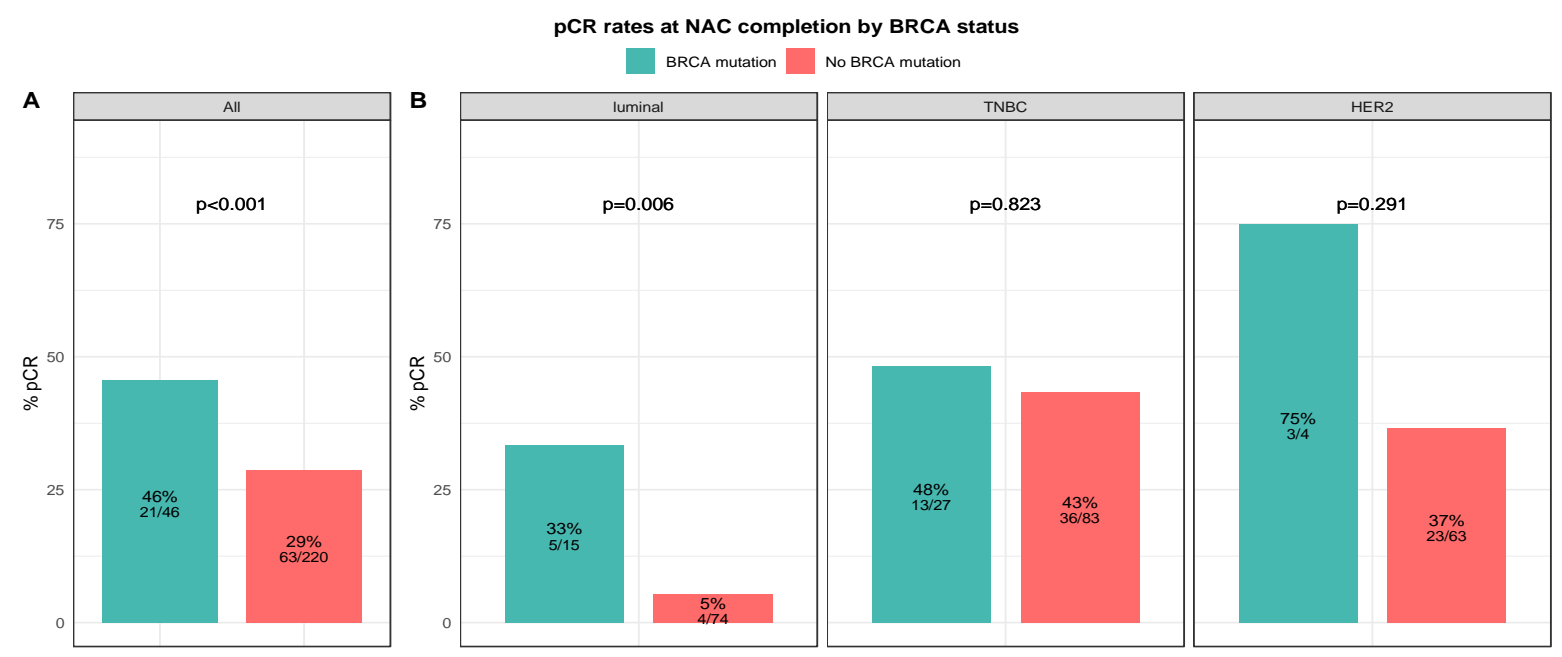

Figure 2. Barplot of associations between response to treatment and $B R C A$ status in whole population, and by breast cancer subtype. A, among the whole population (All( $\mathrm{n}=266), B R C A$ mutation $(\mathrm{n}=46), B R C A$ wild-type $(\mathrm{n}=220)$ ). B, by BC subtype (Luminal( $\mathrm{n}=89), B R C A$ mutation( $\mathrm{n}=15), B R C A$ wild-type $(\mathrm{n}=74)$; $\operatorname{TNBC}(\mathrm{n}=110), B R C A$ mutation $(\mathrm{n}=27), B R C A$ wild-type $(\mathrm{n}=83) ; \operatorname{HER2}(\mathrm{n}=67), B R C A$ mutation $(\mathrm{n}=4)$, $B R C A$ wild-type $(\mathrm{n}=63))$.

However, $B R C A$ status was not significantly associated with pCR after multivariate analysis, and only BC subtype (TNBC, OR = 7.14, CI95\% [ 3.39 - 16.57 ], $p<0.001$; HER2-positive, 
medRxiv preprint doi: https://doi.org/10.1101/2020.09.27.20202515; this version posted September 28, 2020. The copyright holder for this preprint (which was not certified by peer review) is the author/funder, who has granted medRxiv a license to display the preprint in

perpetuity.
It is made available under a CC-BY-ND 4.0 International license .

$1 \quad(\mathrm{OR}=1.03, \mathrm{CI} 95 \%[1.02-1.05], p=0.001$ and $\mathrm{OR}=1.04, \mathrm{CI} 95 \%[1.02-1.07], p=0.002)$

2 were independent predictors of pCR (Supplementary Table S3).

\section{Post-NAC Immune Infiltration by BRCA status}

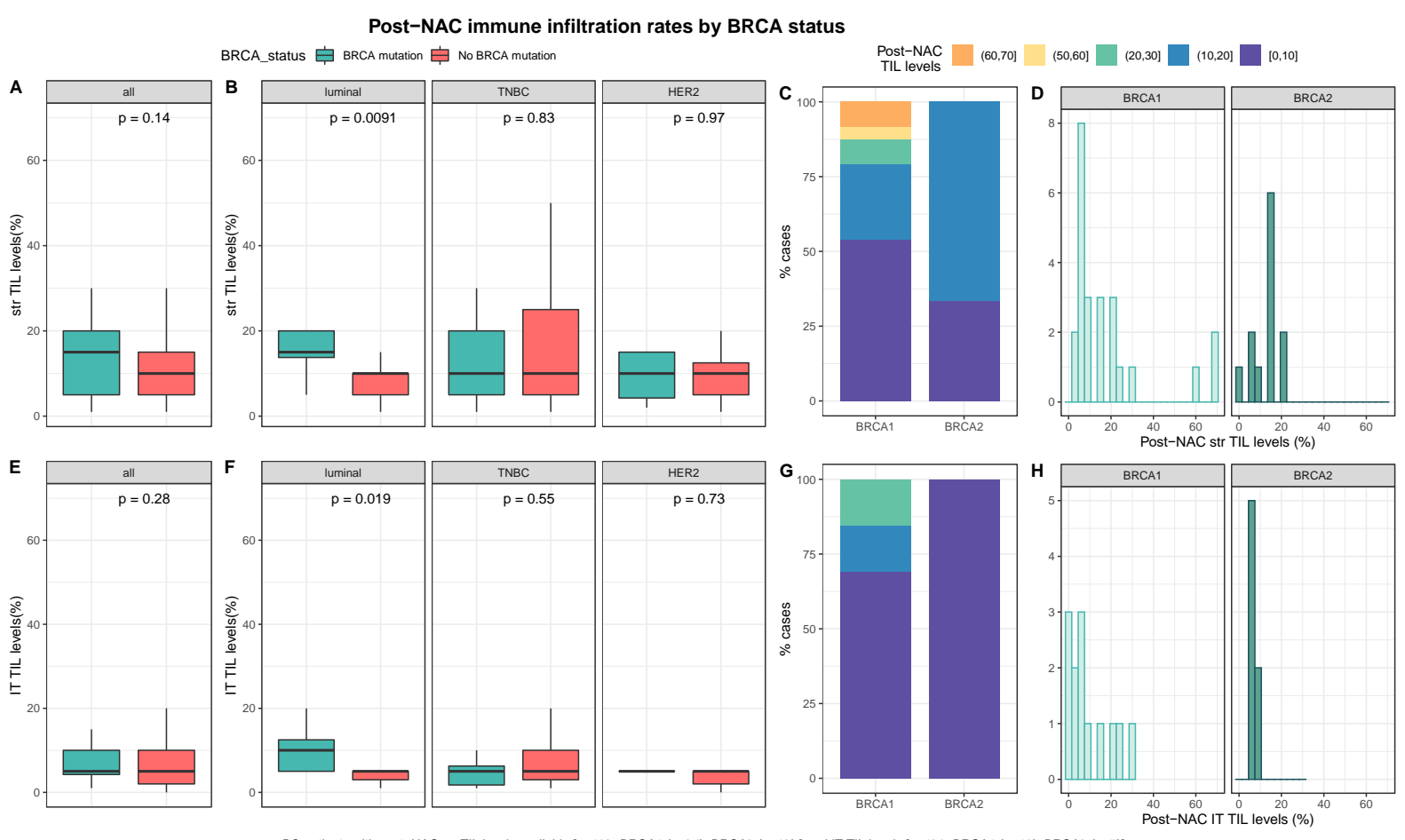

Figure 3. Associations between post-NAC TILs and BRCA status in whole population, and after stratification by breast cancer subtype. Bottom and top bars of the boxplots represent the first and third quartiles, respectively, the medium bar is the median, and whiskers extend to 1.5 times the interquartile range. $A$, stromal lymphocytes among the whole population (All( $n=192), B R C A$ mutation ( $n=36), B R C A$ wild-type $(n=156)$ ). B, stromal lymphocytes in each $B C$ subtype (Luminal $(n=52), B R C A$ mutation $(n=8), B R C A$ wild-type( $n=44)$; TNBC( $n=97)$, $B R C A$ mutation( $\mathrm{n}=24), B R C A$ wild-type $(\mathrm{n}=73) ; H E R 2(\mathrm{n}=43), B R C A$ mutation $(\mathrm{n}=4), B R C A$ wild-type $(\mathrm{n}=39))$. C, Percentage of tumor according to post-NAC stromal lymphocytes levels binned by $10 \%$ increment in patients with $B R C A$-deficient $(B R C A 1(n=24), B R C A 2(n=12)$ ). $D$, distribution of post-NAC stromal lymphocytes by gene mutations (histogram plot) in patients with $B R C A$-deficient $(B R C A 1$ ( $\mathrm{n}=24)$, $B R C A 2(n=12))$. $E$, intratumoral lymphocytes among the whole population (All $(n=120), B R C A$ mutation $(n=20), B R C A$ wild type( $n=100)$ ). $F$, intratumoral lymphocytes in each $B C$ subtype (Luminal $(\mathrm{n}=44), B R C A$ mutation $(\mathrm{n}=7), B R C A$ wild-type( $\mathrm{n}=37)$; TNBC( $\mathrm{n}=50)$, $B R C A$ mutation( $(\mathrm{n}=12), B R C A$ wild-type $(\mathrm{n}=38) ; \operatorname{HER2}(\mathrm{n}=26), B R C A$ mutation( $\mathrm{n}=1), B R C A$ wild-type $(\mathrm{n}=25))$. $\mathbf{G}$, percentage of tumor according to post-NAC intratumoral lymphocytes levels binned by $10 \%$ increment in patients with $B R C A$-deficient $(B R C A 1$ ( $n=13), B R C A 2(n=7)$ ). $H$, distribution of pre-NAC intratumoral lymphocytes by gene mutations (histogram plot) in patients with $B R C A$-deficient $(B R C A 1$ ( $\mathrm{n}=13$ ), BRCA2 $(\mathrm{n}=7)$ ).

After NAC, str and IT TILs were available in 192 (72\%) and 120 (45\%) patients respectively.

Post-NAC immune infiltration (whether intra-tumoral or stromal) was not significantly

Fig. 3A-3E). However, both str and IT TIL levels were significantly higher in tumors with 
medRxiv preprint doi: https://doi.org/10.1101/2020.09.27.20202515; this version posted September 28, 2020. The copyright holder for this preprint (which was not certified by peer review) is the author/funder, who has granted medRxiv a license to display the preprint in It is made available under a CC-BY-ND 4.0 International license.

1 BRCA pathogenic mutations when compared with wild-type tumors in luminal BCs (median

2 str TIL levels: $15 \%$ vs. $10 \%, p=0.009$ and median IT TIL levels : $10 \%$ vs. $5 \%, p=0.019$,

3 respectively, Supplementary Table S2, Figure 3).

4 Median pre-NAC str TIL were higher than after NAC (20\% vs 10\%, 11.95\%), also according

5 to $B R C A$ status and type (Supplementary Table S1, Fig. 4). There was no correlation

6 between pre and post NAC str TILs (correlation coefficient of 0.13 and $p<0.06$,

7 Supplementary Fig. S5A) and there was a weak, positive, linear relationship between pre

8 and post NAC IT TIL levels (correlation coefficient of 0.31 and $p<0.001$, Supplementary

9 Fig. S5B).

10 Survival analysis

11 After a median of follow-up of 90.4 months (range from 0.2 to 187 months), 73 patients

12 experienced relapse, and 38 died. RFS and OS were not significantly different between

13 carriers of a $B R C A$ pathogenic variant and $B R C A$-proficient patients, neither were they in 14 screened population nor after the subgroup analysis of BC subtype (Supplementary Figs. S6$157)$. 
medRxiv preprint doi: https://doi.org/10.1101/2020.09.27.20202515; this version posted September 28, 2020. The copyright holder for this preprint (which was not certified by peer review) is the author/funder, who has granted medRxiv a license to display the preprint in

It is made available under a CC-BY-ND 4.0 International license .

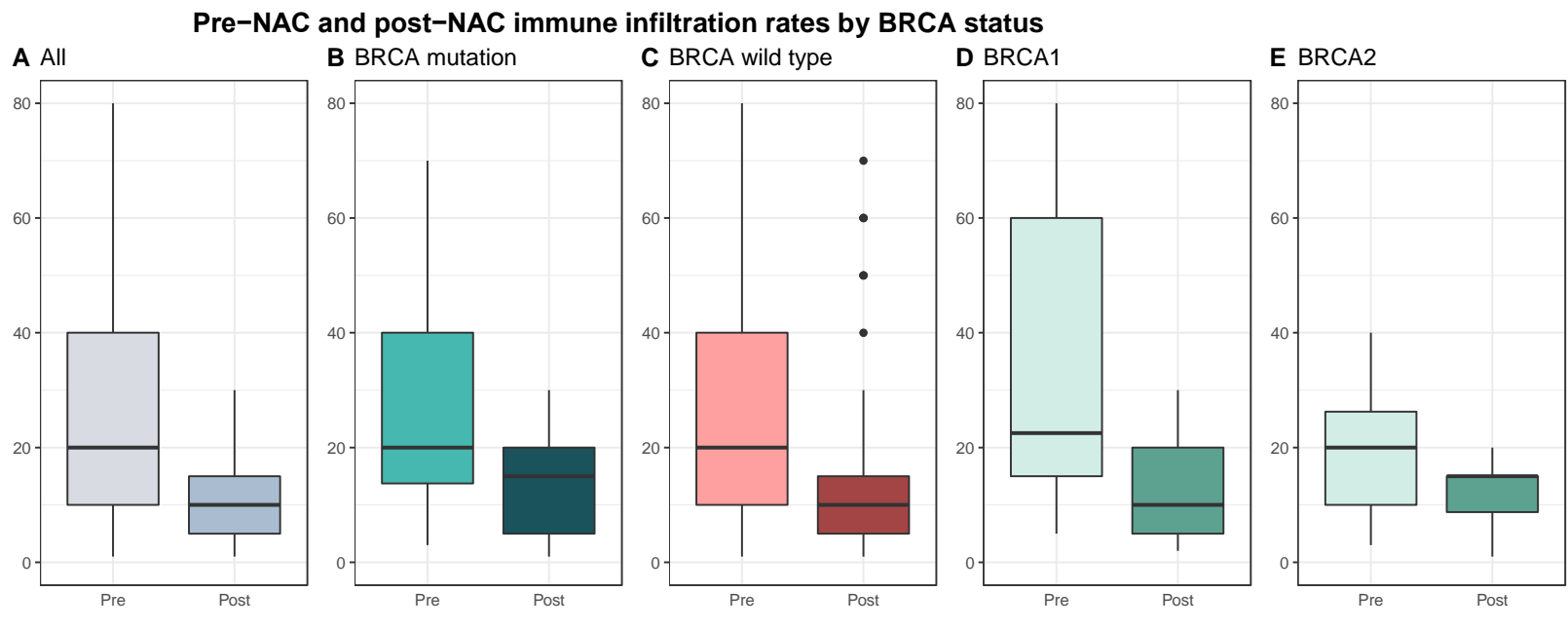

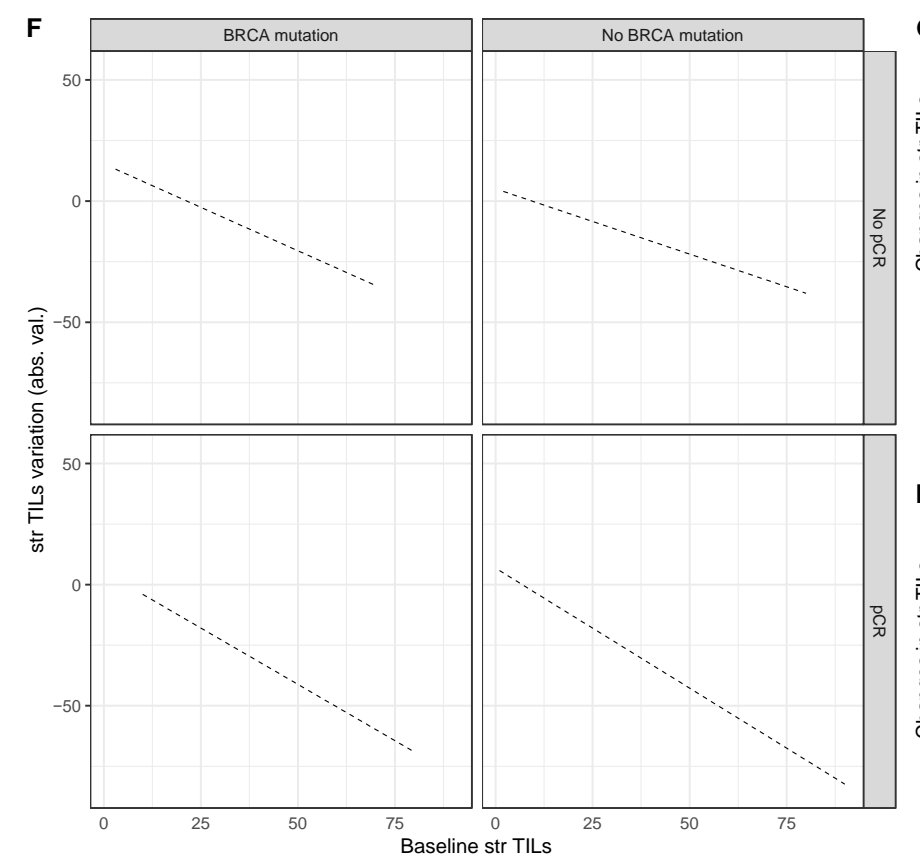

str TILs dynamics No TILs change TILs decrease TILs increase

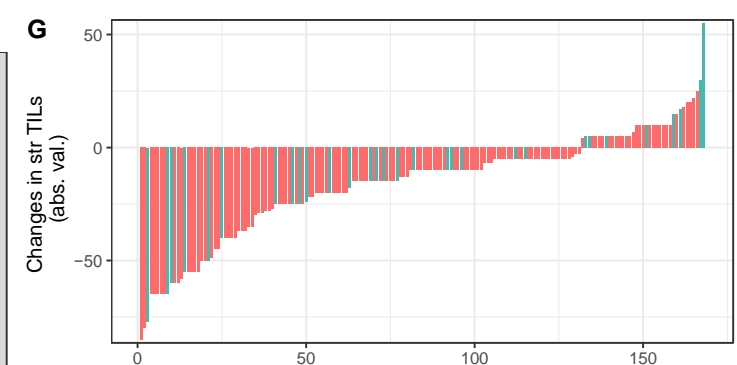

BRCA status BRCA mutation No BRCA mutation

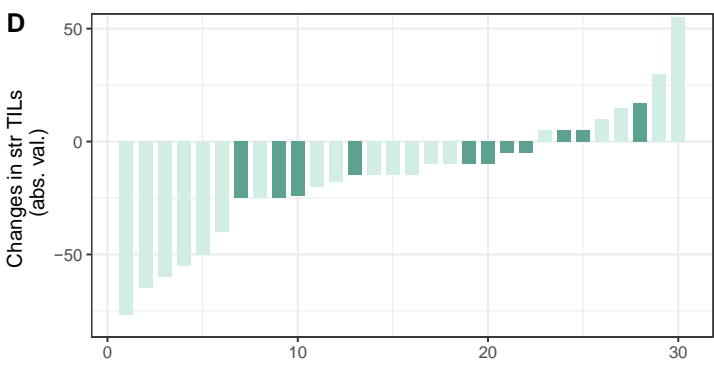

BRCA mutation $\quad$ BRCA1 $\quad$ BRCA2

BC patients with pre and post-NAC str TIL levels available [ $n=192$; BRCA mutation ( $n=36), B R C A$ wild type $(n=156), B R C A 1(n=24), B R C A 2$ ( $n=12)$ ]

Figure 4. Pre-NAC and post-NAC stromal immune infiltration rates in the whole population and by BRCA status. A-E, bar plots of str TIL levels before and after NAC in the whole population and in BRCA pathogenic variant. Bottom and top bars of the boxplots represent the first and third quartiles, respectively, the medium bar is the median, and whiskers extend to 1.5 times the interquartile range. (All( $(n=192)$; $B R C A$ mutation ( $\mathrm{n}=36), B R C A$ wild-type $(\mathrm{n}=156) ; B R C A 1(\mathrm{n}=24), B R C A 2(12))$. $\mathrm{F}$, variation of str TIL levels according to the pre-NAC str TIL levels binned by BRCA status and response to chemotherapy. Points represent the difference between pre- and post-NAC paired TIL levels values of a given patient and are colored according to TIL variation category (TIL level decrease: yellow/no change: green/increase: red) (All( $(\mathrm{n}=191), B R C A$ mutation $(\mathrm{n}=36), B R C A$ wild-type( $\mathrm{n}=155))$. G-D, waterfall plot representing the variation of TIL levels according to $B R C A-$ deficient (BRCA1-deficient, BRCA2-deficient); each bar represents one sample, and samples are ranked by increasing order of TIL level change. Paired samples for which no change was observed have been removed from the graph. (All( $n=191), B R C A$ mutation [( $n=36)$, $B R C A 1, \mathrm{n}=24 ; B R C A 2=12)], B R C A$ wild-type $(\mathrm{n}=155))$. 
medRxiv preprint doi: https://doi.org/10.1101/2020.09.27.20202515; this version posted September 28, 2020. The copyright holder for this preprint (which was not certified by peer review) is the author/funder, who has granted medRxiv a license to display the preprint in

It is made available under a CC-BY-ND 4.0 International license .

\section{Discussion}

2 In the current study, we did not identify any association between BRCA status and immune

3 infiltration whatever the type of TILs (IT, str). We found a better response to neoadjuvant

4 chemotherapy in tumors associated with a germline $B R C A$ pathogenic variant when compared

5 to $B R C A-\mathrm{WT}$, but the latter was limited to the group of luminal BCs and was not statistically

6 significant after multivariate analysis. Probably in relation, we recovered higher post-NAC

7 lymphocyte infiltration in BRCA-deficient tumors in the luminal BC subgroup.

8 Regarding pre-treatment immune infiltration, Sønderstrup and colleagues (25) analyzed str

9 TIL levels in a nationwide cohort of $B R C A 1$ and $B R C A 2$ carriers with primary BCs. They

10 found a greater prevalence of high stromal TILs (defined as TILs-positive tumors with $\geq 60 \%$

11 str TILs) in BRCA1-deficient tumors $(\mathrm{n}=243)$ when compared with BRCA2-deficient tumors

12 ( $\mathrm{n}=168)(36 \%$ versus $15 \%$ respectively, $p<0.0001)$. However, no control group with $B R C A-$

13 WT tumors was available in this study. In a small study of 85 TNBC patients, Solinas and

14 colleagues (26) investigated the distribution of TILs subpopulations. The tumors of patients in

15 the BRCA1 or BRCA2-mutated group displayed a higher prevalence of TILs-positive tumors

16 (defined as tumors with $\geq 10 \%$ str or IT TILs) when compared with the BRCA-WT (93.2\%

17 versus $75.6 \%$ respectively, $p=0.037$ ). No other statistically significant differences were

18 identified between BRCA-carriers and non-carriers, neither in TILs subpopulations nor their

19 location. More recently, Telli and colleagues (27) investigated the association between TILs,

20 homologous recombination deficiency (HDR) and BRCAl/2 status in a cohort of 161 TNBC

21 patients pooled from 5 phase II neoadjuvant clinical trials of platinum-based therapy. They

22 found that IT TILs and str TILs density were not associated with BRCA1/2 status ( $p=0.312$

23 and $p=0.391$, respectively). Consistently with Telli et al, we did not observe any difference

24 in baseline immune infiltration according to $B R C A$ status. 
medRxiv preprint doi: https://doi.org/10.1101/2020.09.27.20202515; this version posted September 28, 2020. The copyright holder for this preprint (which was not certified by peer review) is the author/funder, who has granted medRxiv a license to display the preprint in It is made available under a CC-BY-ND 4.0 International license .

1 Some retrospective studies suggested that tumors displayed higher chemosensitivity

2 according to $B R C A$-mutation status (17-19, 28-35). Arun et al. (31) compared pCR rates after

3 NAC between $B R C A 1$ or $B R C A 2$-carriers ( $\mathrm{n}=57$ and $\mathrm{n}=23$, respectively) and WT controls

$4 \quad(\mathrm{n}=237)$. The majority of patients $(82 \%)$ received an anthracycline-taxane containing regimen

5 as NAC. The authors found that BRCAl mutation was an independent positive predictor of

6 pCR $(\mathrm{OR}=3.16,95 \% \mathrm{CI} 1.55-6.42, p=0.002)$. In the largest study so far, Wunderle et al.(18)

7 investigated efficacy of chemotherapy among a cohort of 355 patients composed with $16.6 \%$

$8(59 / 355)$ of $B R C A$-carriers. Across all BC subtypes, $64.4 \%$ of patients with a $B R C A 1 / 2$

9 pathogenic variant received anthracycline-based treatments, while the rest received

10 carboplatin. pCR was observed in $54.3 \%$ (32/59) of all BRCA1/2 mutation carriers, and in

$1139.5 \%(15 / 34)$ of the BRCA-carriers versus $13 \%$ of the WT BCs in the anthracycline-regimen.

12 In our cohort, we found similar results after univariate analysis, and we additionally

13 evidenced a nearly significant interaction with BC subtype. The fact that our results were no

14 longer significant after multivariate analysis is possibly due to a lack of statistical power.

Furthermore, we found that both str and IT TIL levels were higher after NAC completion in the luminal BCs. Whether this difference in post treatment TILs is a cause, a consequence, or unrelated to response to chemotherapy remains unknown. Indeed, post-NAC TIL levels have been shown to be strongly related to response to chemotherapy in BC cohorts including all BC subtypes (36-38) but only a few studies have investigated the dynamic of TIL levels in response to NAC. Hamy et al.(38) noticed that mean TIL levels decreased after chemotherapy completion across all the BC subtype (pre-NAC TILs: $24.1 \%$ vs. post-NAC TILs: $13.0 \%, p<$ 0.001). This decrease was strongly associated with high pCR rates, and the variation of TIL levels was strongly inversely correlated with pre-NAC TIL levels (and the variation of TIL levels was strongly inversely correlated with pre-NAC TIL levels $(\mathrm{r}=-0.80, p<0.001)$. 
medRxiv preprint doi: https://doi.org/10.1101/2020.09.27.20202515; this version posted September 28, 2020. The copyright holder for this preprint (which was not certified by peer review) is the author/funder, who has granted medRxiv a license to display the preprint in

It is made available under a CC-BY-ND 4.0 International license .

1 Finally, in line with several recently published clinical studies (39-41), we found that survival

2 outcomes were not different between $B R C A$-carriers and non-carriers. A multivariate study,

3 including $223 \mathrm{BC}$ patients carrying $B R C A$ pathogenic variants and 446 controls with sporadic

4 BC matched for age and year of diagnosis, showed no difference in terms of specific BC

5 survival between BRCA1 or BRCA2 mutation carriers and controls (42). Templeton et al.

6 evaluated a total of 16 studies comprising data from 10,180 patients and concluded that $B R C A$

7 pathogenic mutations were not associated with a worse overall survival (43).

8 Limits of our study include its retrospective design as well as small effectives potentially

9 leading to a lack of statistical power. Moreover the incidence of bi-allelic pathogenic

10 alterations in HR-related genes according to somatic origin is well-known and ranches from 1

11 to $2 \%$ (44) but we did not explore somatic mutational status in the tumor tissues in the

12 current study.

13 It also has several strengths, for instance by being the largest cohort with a $B R C A$-WT control 14 group, and analyses performed after stratification by BC subtype. Finally, to our knowledge, 15 we provide data on post-NAC immune infiltration according to $B R C A$ status for the first time.

16 Our study has several implications. First, it generates an unprecedented hypothesis that

17 luminal $\mathrm{BC}$ patients with germline $B R C A$ pathogenic variants may represent a subset of 18 luminal $\mathrm{BCs}$ that are more likely to benefit from chemotherapy as primary treatment than the 19 whole luminal BC population. It is known that the absolute benefit of chemotherapy is lower 20 in luminal $\mathrm{BC}$ than in the other BC subtypes (45). If further validated in independent cohorts, 21 our findings might lead to reconsider standard use of chemotherapy in patients with luminal 22 BC associated with BRCA pathogenic mutations. Second, patients not achieving pCR may be 23 candidates for post-operative clinical trials exploring alternative therapeutic strategies. As 24 post-NAC immune infiltration seems to be higher in post-NAC specimens of luminal tumors 
medRxiv preprint doi: https://doi.org/10.1101/2020.09.27.20202515; this version posted September 28, 2020. The copyright holder for this preprint (which was not certified by peer review) is the author/funder, who has granted medRxiv a license to display the preprint in It is made available under a CC-BY-ND 4.0 International license .

1 with $B R C A$ pathogenic mutations, we can hypothesize that those tumors would be more likely

2 to respond to checkpoint inhibitors after chemotherapy. Second line trials using immune

3 checkpoint inhibitors (such as anti-PD-1 and anti-PD-L1 antibodies) alone or in combination,

4 together with endocrine therapy could be a relevant strategy for patients failing to reach pCR

5 at NAC completion. 


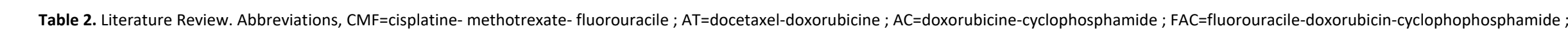
CEF=cyclophosphamide-epirubicine-fluorouracile ; $\mathrm{A}=$ anthracycline ; Dx=doxorubicine ; Do=docetaxel ; Cb=carboplatin ; Cis=cisplatine ; BEV=bevacizumab ; PTX=paclitaxel ; T=taxane.

\begin{tabular}{|c|c|c|c|c|c|c|c|c|c|c|c|c|c|c|}
\hline Study & Setting / Design & 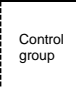 & $\begin{array}{l}\begin{array}{l}\text { Number of } \\
\text { patient } \\
(n)\end{array} \\
\text { (n) }\end{array}$ & $\begin{array}{l}\text { TNBC } \\
(n)\end{array}$ & $\begin{array}{l}\text { HER2 } \\
\text { positive } \\
\text { (n) }\end{array}$ & $\underset{\substack{\text { Luminal } \\
(n)}}{2}$ & BRCA1 & BRCA2 & $\begin{array}{l}\text { BRCA } 1 \\
\text { and } 2\end{array}$ & $\begin{array}{l}\text { Chemotherapy } \\
\text { regimen }\end{array}$ & $\begin{array}{l}\text { sTiLs } \\
\text { evaluation }\end{array}$ & $\begin{array}{ll}\text { PCR } \\
\text { BRA. } \\
\text { cariers } \\
\text { non-cariers }\end{array}$ & $\begin{array}{l}\text { survival } \\
\text { analyses }\end{array}$ & Comments \\
\hline $\begin{array}{l}\text { Chappuis (2002) } \\
\text { J Jurnal } \\
\text { Medical of } \\
\text { Genetics }\end{array}$ & $\begin{array}{l}\text { Neadijuant } \\
\text { Rertsospetiviv } \\
\text { clinical trial }\end{array}$ multicentric & Yes & 38 & NA & NA & NA & 7 & 4 & 0 & $\begin{array}{l}\text { FAC } \\
\text { AC } \\
C E F \\
A C+ \\
A C+D\end{array} \quad C M F$ & No & $44 \%$ vs $4 \%$ & No & 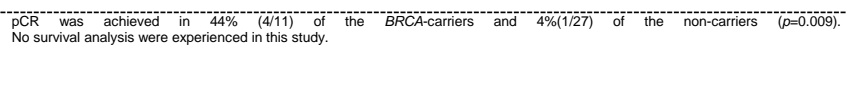 \\
\hline $\begin{array}{c}\text { Byrsti } \\
\text { JcO }\end{array}$ & $\begin{array}{l}\text { Neoadiuvant } \\
\text { EDedidemiologic retrospective } \\
\text { conot } \\
\text { (nationwide) }\end{array}$ & No & 102 & NA & 6 & $\mathrm{NA}$ & 102 & 0 & 0 & 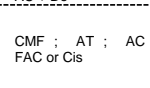 & No & $23.5 \%$ & № & 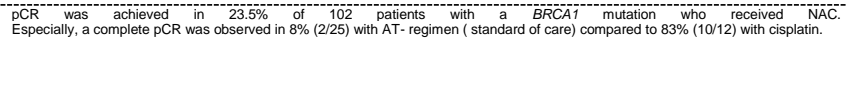 \\
\hline $\begin{array}{ll}\text { Arun } \\
\text { JCO }\end{array}$ & $\begin{array}{l}\text { Neoadjuvant } \\
\text { Epedemilologic retrospective } \\
\text { conorit }\end{array}$ & Yes & 317 & 77 & 60 & NA & 57 & 23 & 0 & $\begin{array}{l}\text { A-single agent; AT } \\
\text { or T-single-agent }\end{array}$ & No & $46 \%$ vs $22 \%$ & Yes & 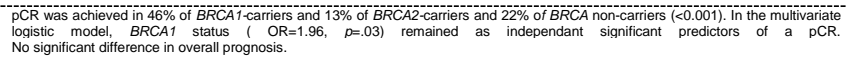 \\
\hline $\begin{array}{l}\text { Wang } \\
\text { Anals } \\
\text { Oncology }\end{array}$ & $\begin{array}{l}\text { Neoadivant } \\
\text { EFidemilologic retrospective } \\
\text { cohort }\end{array}$ & Yes & 652 & 652 & 0 & 0 & 52 & $\mathrm{NA}$ & 0 & $\begin{array}{l}\text { A-single agent; } A T \\
\text { or T-single-agent }\end{array}$ & No & ${ }_{29.7 \%}^{53.8 \%}$ vs & Yes & 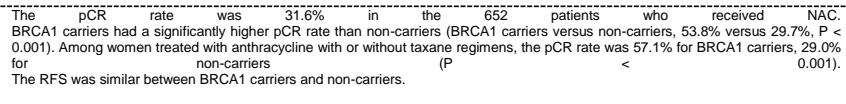 \\
\hline $\begin{array}{ll}\text { Byrski } \\
\text { BCRT }\end{array}$ & 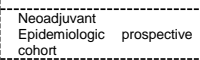 & No & 10 & 10 & 0 & 0 & 10 & 0 & 0 & cis & No & $90 \%$ & № & 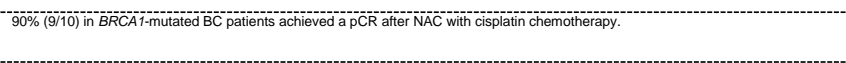 \\
\hline $\begin{array}{l}\text { Byrski } \\
\text { HCCP }\end{array}$ & $\begin{array}{l}\text { Neoadiuvant } \\
\text { Epidemilologic prospective } \\
\text { cohort }\end{array}$ & № & 107 & 82 & 2 & NA & 107 & 0 & 0 & cis & No & $61 \%$ & No & 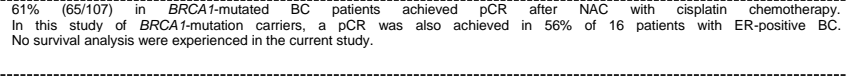 \\
\hline $\begin{array}{l}\text { Paluch-Shimon } \\
\text { (2016): } \\
\text { BCRT }\end{array}$ & $\begin{array}{l}\text { Neoadiuvant } \\
\text { Epidemiologic retrospective } \\
\text { conortt }\end{array}$ & Yes & 80 & 80 & 0 & 0 & 34 & 0 & 0 & AT & No & $68 \%$ vs $37 \%$ & Yes & 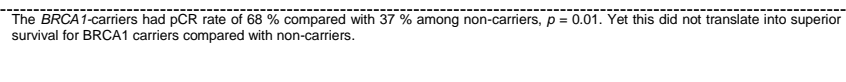 \\
\hline $\begin{array}{c}\text { Bignon } \\
\text { Breast }\end{array}$ & $\begin{array}{l}\text { Neoadiuvant } \\
\text { EDidemiologic retrospective } \\
\text { conortt }\end{array}$ & No & 53 & 53 & 0 & 0 & 46 & 6 & 1 & A-single agent or $A T$ & No & $66 \%$ & Yes & 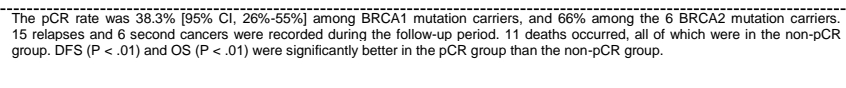 \\
\hline $\begin{array}{l}\text { Hanhen (2017) } \\
\text { JAMA o oncology }\end{array}$ & 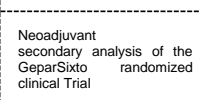 & Yes & 291 & 291 & 0 & 0 & 50 & & 0 & $A T+B E V+/-C$ is & No & $\begin{array}{l}6.7 .7 \% \text { vs } \\
36.4 \%\end{array}$ & Yes & 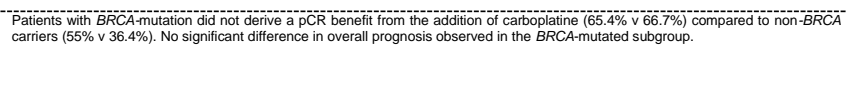 \\
\hline $\begin{array}{l}\text { Shama (2017) } \\
\text { CCR }\end{array}$ & 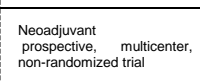 & Yes & 190 & 190 & 0 & 0 & 30 & & 0 & $C b+D o$ & No & $59 \%$ vs $56 \%$ & No & 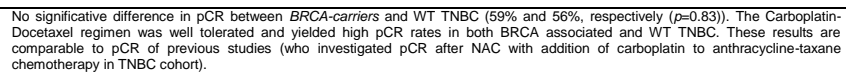 \\
\hline $\begin{array}{l}\text { Wunderle (2018) } \\
\text { BCRT }\end{array}$ & $\begin{array}{l}\text { Neoadjuvant } \\
\text { Epididemilogic retrospective } \\
\text { cohort }\end{array}$ & Yes & 355 & 138 & 58 & 159 & 43 & 16 & 0 & $\mathrm{AT} ; \mathrm{Cb}$ & No & ${ }_{12.6 \%}^{54.3 \%}$ vs & Yes & 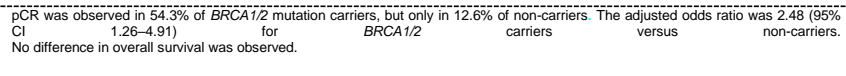 \\
\hline $\begin{array}{l}\text { Saether (2018) } \\
\text { HCCP }\end{array}$ & 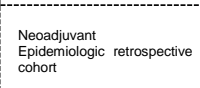 & No & 12 & NA & NA & NA & 12 & 0 & 0 & $\begin{array}{c}C_{C b}^{c i s} D_{0}^{+} \\
C b x\end{array}$ & No & $83 \%$ & № & 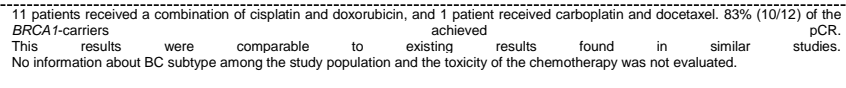 \\
\hline $\begin{array}{l}\text { Sella } \\
\text { Breast }\end{array}$ & $\begin{array}{l}\text { Neoadjuvant } \\
\text { Eppidemilologic retrospective } \\
\text { cohort }\end{array}$ & Yes & 43 & 43 & 0 & 0 & 14 & 0 & 0 & $\mathrm{AT}+\mathrm{Cb}$ & No & $67 \%$ vs $38 \%$ & No & 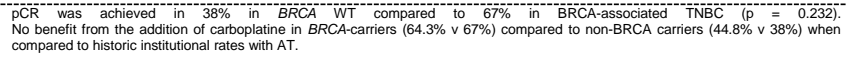 \\
\hline $\begin{array}{ll}\text { Telli } \\
\text { CCR }\end{array}$ & ${ }_{11}^{5}$ pooled analyses of phase & Yes & 161 & 161 & 0 & 0 & 34 & & 0 & $\begin{array}{ll} & \\
C & \end{array}$ & Yes & No & No & 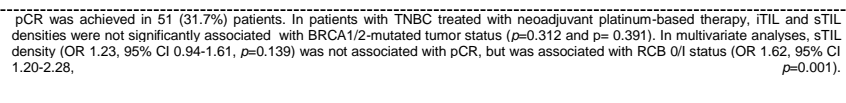 \\
\hline $\begin{array}{l}\text { Solinas (2019) } \\
\text { Cancor_Leters }\end{array}$ & $\begin{array}{l}\text { Epidemiologic retrospective } \\
\text { conotor }\end{array}$ & Yes & 85 & 85 & 0 & 0 & 38 & 6 & 0 & NA & Yes & № & Yes & 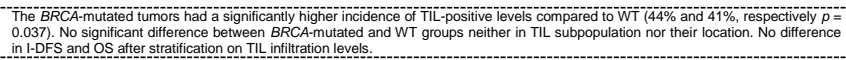 \\
\hline $\begin{array}{l}\text { Sonderstrup } \\
\text { (2019) } \\
\text {-Acta-Onocologica. }\end{array}$ & $\begin{array}{l}\text { Epidemilologic } \\
\text { muliticentric } \\
\text { (nationide }\end{array}$ & No & 411 & $\mathrm{NA}$ & 24 & $\mathrm{NA}$ & 243 & 168 & 0 & NA & Yes & No & Yes & 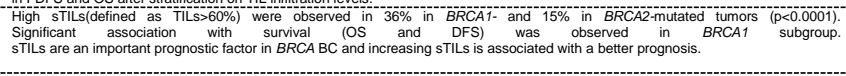 \\
\hline Our study (2020) & $\begin{array}{l}\text { Epidemiologic prospective } \\
\text { cohort }\end{array}$ & Yes & 267 & 110 & 67 & 90 & 31 & 14 & 1 & $\begin{array}{l}\text { A-single agent; AT } \\
\text { or T-single-agent }\end{array}$ & Yes & $\begin{array}{l}45.7 \% \text { vs } \\
28.6 \%\end{array}$ & Yes & 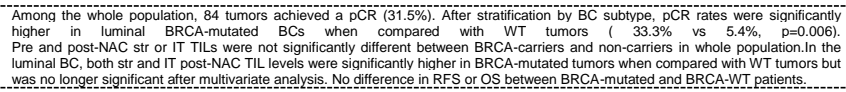 \\
\hline
\end{tabular}


medRxiv preprint doi: https://doi.org/10.1101/2020.09.27.20202515; this version posted September $28,2020$. The copyright holder for this preprint (which was not certified by peer review) is the author/funder, who has granted medRxiv a license to display the preprint in It is made available under a CC-BY-ND 4.0 International license .

\section{References:}

1. Rastogi P, Anderson SJ, Bear HD, Geyer CE, Kahlenberg MS, Robidoux A, et al. Preoperative chemotherapy: updates of National Surgical Adjuvant Breast and Bowel Project Protocols B-18 and B-27. J Clin Oncol Off J Am Soc Clin Oncol. 2008;26:77885.

2. Reyal F, Hamy AS, Piccart MJ. Neoadjuvant treatment: the future of patients with breast cancer. ESMO Open. 2018;3:e000371.

3. Luangdilok S, Samarnthai N, Korphaisarn K. Association between Pathological Complete Response and Outcome Following Neoadjuvant Chemotherapy in Locally Advanced Breast Cancer Patients. J Breast Cancer. 2014;17:376-85.

4. Huang K-L, Mashl RJ, Wu Y, Ritter DI, Wang J, Oh C, et al. Pathogenic Germline Variants in 10,389 Adult Cancers. Cell. 2018;173:355-370.e14.

5. Kuchenbaecker KB, Hopper JL, Barnes DR, Phillips K-A, Mooij TM, Roos-Blom M-J, et al. Risks of Breast, Ovarian, and Contralateral Breast Cancer for BRCA1 and BRCA2 Mutation Carriers. JAMA. 2017;317:2402-16.

6. Ferreira EN, Brianese RC, de Almeida RVB, Drummond RD, de Souza JE, da Silva IT, et al. Influence of BRCA1 Germline Mutations in the Somatic Mutational Burden of TripleNegative Breast Cancer. Transl Oncol. 2019;12:1453-60.

7. Eisinger F, Jacquemier J, Charpin C, Stoppa-Lyonnet D, Bressac-de Paillerets B, Peyrat JP, et al. Mutations at BRCA1: the medullary breast carcinoma revisited. Cancer Res. 1998;58:1588-92.

8. Phillips KA. Immunophenotypic and pathologic differences between BRCA1 and BRCA2 hereditary breast cancers. J Clin Oncol Off J Am Soc Clin Oncol. 2000;18:107S-12S.

9. Mavaddat N, Barrowdale D, Andrulis IL, Domchek SM, Eccles D, Nevanlinna H, et al. Pathology of breast and ovarian cancers among BRCA1 and BRCA2 mutation carriers: results from the Consortium of Investigators of Modifiers of BRCA1/2 (CIMBA). Cancer Epidemiol Biomark Prev Publ Am Assoc Cancer Res Cosponsored Am Soc Prev Oncol. 2012;21:134-47.

10. Lakhani SR, Van De Vijver MJ, Jacquemier J, Anderson TJ, Osin PP, McGuffog L, et al. The pathology of familial breast cancer: predictive value of immunohistochemical markers estrogen receptor, progesterone receptor, HER-2, and p53 in patients with mutations in BRCA1 and BRCA2. J Clin Oncol Off J Am Soc Clin Oncol. 2002;20:23108.

11. Armes JE, Trute L, White D, Southey MC, Hammet F, Tesoriero A, et al. Distinct molecular pathogeneses of early-onset breast cancers in BRCA1 and BRCA2 mutation carriers: a population-based study. Cancer Res. 1999;59:2011-7.

12. Palacios J, Honrado E, Osorio A, Cazorla A, Sarrió D, Barroso A, et al. Phenotypic characterization of BRCA1 and BRCA2 tumors based in a tissue microarray study with 37 immunohistochemical markers. Breast Cancer Res Treat. 2005;90:5-14. 
medRxiv preprint doi: https://doi.org/10.1101/2020.09.27.20202515; this version posted September $28,2020$. The copyright holder for this preprint (which was not certified by peer review) is the author/funder, who has granted medRxiv a license to display the preprint in It is made available under a CC-BY-ND 4.0 International license .

13. Lakhani SR, Reis-Filho JS, Fulford L, Penault-Llorca F, van der Vijver M, Parry S, et al. Prediction of BRCA1 status in patients with breast cancer using estrogen receptor and basal phenotype. Clin Cancer Res Off J Am Assoc Cancer Res. 2005;11:5175-80.

14. Denkert C, Liedtke C, Tutt A, von Minckwitz G. Molecular alterations in triple-negative breast cancer-the road to new treatment strategies. Lancet Lond Engl. 2017;389:2430-42.

15. Mancini P, Angeloni A, Risi E, Orsi E, Mezi S. Standard of Care and Promising New Agents for Triple Negative Metastatic Breast Cancer. Cancers. 2014;6:2187-223.

16. Godet I, Gilkes DM. BRCA1 and BRCA2 mutations and treatment strategies for breast cancer. Integr Cancer Sci Ther [Internet]. 2017 [cited 2019 Dec 17];4. Available from: https://www.ncbi.nlm.nih.gov/pmc/articles/PMC5505673/

17. Byrski T, Gronwald J, Huzarski T, Grzybowska E, Budryk M, Stawicka M, et al. Pathologic Complete Response Rates in Young Women With BRCA1-Positive Breast Cancers After Neoadjuvant Chemotherapy. J Clin Oncol. 2009;28:375-9.

18. Wunderle M, Gass P, Häberle L, Flesch VM, Rauh C, Bani MR, et al. BRCA mutations and their influence on pathological complete response and prognosis in a clinical cohort of neoadjuvantly treated breast cancer patients. Breast Cancer Res Treat. 2018;171:85-94.

19. Sella T, Gal Yam EN, Levanon K, Rotenberg TS, Gadot M, Kuchuk I, et al. Evaluation of tolerability and efficacy of incorporating carboplatin in neoadjuvant anthracycline and taxane based therapy in a BRCA1 enriched triple-negative breast cancer cohort. Breast Edinb Scotl. 2018;40:141-6.

20. Solinas C, Ceppi M, Lambertini M, Scartozzi M, Buisseret L, Garaud S, et al. Tumorinfiltrating lymphocytes in patients with HER2-positive breast cancer treated with neoadjuvant chemotherapy plus trastuzumab, lapatinib or their combination: A metaanalysis of randomized controlled trials. Cancer Treat Rev. 2017;57:8-15.

21. Solinas C, Carbognin L, De Silva P, Criscitiello C, Lambertini M. Tumor-infiltrating lymphocytes in breast cancer according to tumor subtype: Current state of the art. Breast Edinb Scotl. 2017;35:142-50.

22. [Recommendations for the immunohistochemistry of the hormonal receptors on paraffin sections in breast cancer. Update 1999. Group for Evaluation of Prognostic Factors using Immunohistochemistry in Breast Cancer (GEFPICS-FNCLCC)]. Ann Pathol. 1999;19:336-43.

23. Salgado R, Denkert C, Demaria S, Sirtaine N, Klauschen F, Pruneri G, et al. The evaluation of tumor-infiltrating lymphocytes (TILs) in breast cancer: recommendations by an International TILs Working Group 2014. Ann Oncol Off J Eur Soc Med Oncol. 2015;26:259-71.

24. Dieci MV, Radosevic-Robin N, Fineberg S, van den Eynden G, Ternes N, Penault-Llorca $\mathrm{F}$, et al. Update on tumor-infiltrating lymphocytes (TILs) in breast cancer, including recommendations to assess TILs in residual disease after neoadjuvant therapy and in carcinoma in situ: A report of the International Immuno-Oncology Biomarker Working Group on Breast Cancer. Semin Cancer Biol. 2018;52:16-25. 
25. Sønderstrup IMH, Jensen MB, Ejlertsen B, Eriksen JO, Gerdes AM, Kruse TA, et al. Evaluation of tumor-infiltrating lymphocytes and association with prognosis in BRCAmutated breast cancer. Acta Oncol Stockh Swed. 2019;58:363-70.

26. Solinas C, Marcoux D, Garaud S, Vitória JR, Van den Eynden G, de Wind A, et al. BRCA gene mutations do not shape the extent and organization of tumor infiltrating lymphocytes in triple negative breast cancer. Cancer Lett. 2019;450:88-97.

27. Telli ML, Chu C, Badve SS, Vinayak S, Silver DP, Isakoff SJ, et al. Association of Tumor Infiltrating Lymphocytes with Homologous Recombination Deficiency and BRCA1/2 Status in Patients with Early Triple-Negative Breast Cancer: A Pooled Analysis. Clin Cancer Res Off J Am Assoc Cancer Res. 2019;

28. Chappuis P, Goffin J, Wong N, Perret C, Ghadirian P, Tonin P, et al. A significant response to neoadjuvant chemotherapy in BRCA1/2 related breast cancer. J Med Genet. 2002;39:608-10.

29. Byrski T, Huzarski T, Dent R, Marczyk E, Jasiowka M, Gronwald J, et al. Pathologic complete response to neoadjuvant cisplatin in BRCA1-positive breast cancer patients. Breast Cancer Res Treat. 2014;147:401-5.

30. Byrski T, Huzarski T, Dent R, Marczyk E, Jasiowka M, Gronwald J, et al. Pathological complete response to neoadjuvant cisplatin in BRCA1-positive breast cancer patients. Hered Cancer Clin Pract. 2015;13:A8.

31. Arun B, Bayraktar S, Liu DD, Gutierrez Barrera AM, Atchley D, Pusztai L, et al. Response to Neoadjuvant Systemic Therapy for Breast Cancer in BRCA Mutation Carriers and Noncarriers: A Single-Institution Experience. J Clin Oncol. 2011;29:373946.

32. Silver DP, Richardson AL, Eklund AC, Wang ZC, Szallasi Z, Li Q, et al. Efficacy of neoadjuvant Cisplatin in triple-negative breast cancer. J Clin Oncol Off J Am Soc Clin Oncol. 2010;28:1145-53.

33. Paluch-Shimon S, Cardoso F, Sessa C, Balmana J, Cardoso MJ, Gilbert F, et al. Prevention and screening in BRCA mutation carriers and other breast/ovarian hereditary cancer syndromes: ESMO Clinical Practice Guidelines for cancer prevention and screening†. Ann Oncol. 2016;27:v103-10.

34. Hahnen E, Lederer B, Hauke J, Loibl S, Kröber S, Schneeweiss A, et al. Germline Mutation Status, Pathological Complete Response, and Disease-Free Survival in TripleNegative Breast Cancer. JAMA Oncol. 2017;3:1378-85.

35. Sæther NH, Skuja E, Irmejs A, Maksimenko J, Miklasevics E, Purkalne G, et al. Platinum-based neoadjuvant chemotherapy in BRCA1-positive breast cancer: a retrospective cohort analysis and literature review. Hered Cancer Clin Pract [Internet]. 2018 [cited 2019 Oct 27];16. Available from: https://www.ncbi.nlm.nih.gov/pmc/articles/PMC5924493/

36. Ali HR, Dariush A, Provenzano E, Bardwell H, Abraham JE, Iddawela M, et al. Computational pathology of pre-treatment biopsies identifies lymphocyte density as a 
medRxiv preprint doi: https://doi.org/10.1101/2020.09.27.20202515; this version posted September 28,2020 . The copyright holder for this preprint (which was not certified by peer review) is the author/funder, who has granted medRxiv a license to display the preprint in

It is made available under a CC-BY-ND 4.0 International license .

predictor of response to neoadjuvant chemotherapy in breast cancer. Breast Cancer Res BCR. 2016;18:21.

37. Ali HR, Dariush A, Thomas J, Provenzano E, Dunn J, Hiller L, et al. Lymphocyte density determined by computational pathology validated as a predictor of response to neoadjuvant chemotherapy in breast cancer: secondary analysis of the ARTemis trial. Ann Oncol Off J Eur Soc Med Oncol. 2017;28:1832-5.

38. Hamy A-S, Bonsang-Kitzis H, De Croze D, Laas E, Darrigues L, Topciu L, et al. Interaction between Molecular Subtypes and Stromal Immune Infiltration before and after Treatment in Breast Cancer Patients Treated with Neoadjuvant Chemotherapy. Clin Cancer Res Off J Am Assoc Cancer Res. 2019;25:6731-41.

39. Yadav S, Ladkany R, Yadav D, Alhalabi O, Khaddam S, Isaac D, et al. Impact of BRCA Mutation Status on Survival of Women With Triple-negative Breast Cancer. Clin Breast Cancer. 2018;18:e1229-35.

40. Xie Y, Gou Q, Wang Q, Zhong X, Zheng H. The role of BRCA status on prognosis in patients with triple-negative breast cancer. Oncotarget. 2017;8:87151-62.

41. Copson ER, Maishman TC, Tapper WJ, Cutress RI, Greville-Heygate S, Altman DG, et al. Germline BRCA mutation and outcome in young-onset breast cancer (POSH): a prospective cohort study. Lancet Oncol. 2018;19:169-80.

42. Brekelmans CTM, Tilanus-Linthorst MMA, Seynaeve C, vd Ouweland A, MenkePluymers MBE, Bartels CCM, et al. Tumour characteristics, survival and prognostic factors of hereditary breast cancer from BRCA2-, BRCA1- and non-BRCA1/2 families as compared to sporadic breast cancer cases. Eur J Cancer Oxf Engl 1990. 2007;43:867-76.

43. Templeton AJ, Gonzalez LD, Vera-Badillo FE, Tibau A, Goldstein R, Šeruga B, et al. Interaction between Hormonal Receptor Status, Age and Survival in Patients with BRCA1/2 Germline Mutations: A Systematic Review and Meta-Regression. PloS One. 2016;11:e0154789.

44. Riaz N, Blecua P, Lim RS, Shen R, Higginson DS, Weinhold N, et al. Pan-cancer analysis of bi-allelic alterations in homologous recombination DNA repair genes. Nat Commun. 2017;8:857.

45. Cardoso F, Kyriakides S, Ohno S, Penault-Llorca F, Poortmans P, Rubio IT, et al. Early breast cancer: ESMO Clinical Practice Guidelines for diagnosis, treatment and followup†. Ann Oncol Off J Eur Soc Med Oncol. 2019;30:1194-220. 


\section{Supplementary material}

\section{Patients and treatments}

\subsection{Patients}

In total, patients with T1-3NxM0 invasive breast cancer (BC) (NEOREP Cohort, CNIL declaration number 1547270) treated at Institut Curie (Paris and Saint Cloud) between 2002 and 2012 were included in this study. We included unilateral, non-recurrent, noninflammatory, non-metastatic tumors, excluding T4 tumors. NAC regimens changed over time (anthracycline-based regimen or sequential anthracycline-taxane regimen) with trastuzumab used in an adjuvant and/or neoadjuvant setting since 2005 for HER2-positive tumors. All patients underwent radiotherapy. Endocrine therapy (tamoxifen or aromatase inhibitor) was prescribed when indicated. This study was approved by the Breast Cancer Study Group of Institut Curie.

\subsection{Treatments}

NAC regimens changed over time (anthracycline-based regimen or sequential anthracyclinetaxane regimen), with trastuzumab used in an adjuvant and/or neoadjuvant setting for HER2positive tumors since the middle of the past decade. Trastuzumab treatments changer over time due to a change of marketing authorization during the study period. Adjuvant hormone therapy (tamoxifen, aromatase inhibitor, or GnRH agonist) was prescribed when indicated. Surgery (breast-conserving or mastectomy) was performed 4-6 weeks after NAC. Every patient received adjuvant radiotherapy. Adjuvant chemotherapy (ADJ) was decided after multidisciplinary consultation meeting considering patient characteristic, prognosis factor and response to NAC (residual disease and/or node involvement). Patient follow-up after treatment was of every 4 months during the first 2 years, then every 6 months for 3 years, and 
once a year starting from the $5^{\text {th }}$ year. Follow-up consisted of clinical examination associated to mammography and mammary ultrasound once a year, with annual Magnetic resonance imaging (RMI) in $B R C A$-carriers.

\section{Tumor samples and pathological review}

\subsection{ER, PR, HER2 status and BC subtype}

Cases were considered to be estrogen receptor (ER)-positive or progesterone receptor (PR)positive if at least $10 \%$ of the tumor cells expressed estrogen and/or progesterone receptors (ER/PR). HER2 expression was determined by immunohistochemistry, with scoring according to the American Society of Clinical Oncology (ASCO)/College of American Pathologists (CAP) guidelines (1). Scores of 3+ were reported as positive, and scores of $1+/ 0$ as negative. Tumors with scores of $2+$ were further tested by fluorescence in situ hybridization (FISH). For HER2 gene amplification, we evaluated a mean of 40 tumor cells per sample and calculated the mean $H E R 2$ signal per nucleus. A $H E R 2 / \mathrm{CEN} 17$ ratio $\geq 2$ was considered positive, and a ratio $<2$ was considered negative (1).

\subsection{Other pathological parameters}

Histological grade was determined as described by Elston Ellis. Mitotic cells were counted on 10 high-power fields (HPF) (x40 objective; field diameter $=0.62 \mathrm{~mm})$ and cutoffs of $<11,12-$ 22 and >22 mitoses were used to define low, intermediate and high mitotic indices, respectively, according to the international recommendations(2). Due to significant differences in distribution before and after NAC, invasive tumor cellularity was binned according to the median value (pre-NAC: $60 \%$; post-NAC: $30 \%$ ).

\section{3 BRCA status}


Since 2002, patient referral for genetic counseling depends on individual or family criteria. These criteria are based on the probability of identifying a genetic predisposition in the family of at least $10 \%$ (in particular a germline BRCAl or BRCA 2 pathogenic variant). The individual criteria are: early age at diagnosis (under 40) or bilateral breast cancer: synchronous or metachronous (with the first breast cancer before age 50), or specific phenotype (triple negative cancer before age 51).The family criteria are: 3 cases of breast cancer in the same branch of heredity, or 2 cases of breast cancer including 1 under 45-50, of breast or ovarian cancer, or 2 cases of breast cancer including 1 male. The 2 cases are women relatives of the first degree (or second degree if paternal transmission).

\subsection{TILs levels}

Infiltrates were scored on a continuous scale, as the mean percentage of the stromal area occupied by mononuclear cells. After NAC, we assessed TIL levels within the borders of the residual tumor bed, as defined by the RCB index(3). Nothing is known about the clinical, biological and prognostic significance of TILs in the area of regression in cases of pathological response, but the TILs international working group recently called for their evaluation for research purposes. In cases of pCR, the scar area was measured on macroscopic examination. The scar appeared as a white area in the breast parenchyma corresponding to the tumor bed modified by NAC. It was characterized by the presence of histiocytes, lymphocytes, macrophages, fibrosis and elastosis. The whole fibro-inflammatory scar was evaluated on HE sections (size in mm and stromal TIL level evaluation). 


\section{References}

1. Wolff AC, Hammond MEH, Schwartz JN, Hagerty KL, Allred DC, Cote RJ, et al. American Society of Clinical Oncology/College of American Pathologists guideline recommendations for human epidermal growth factor receptor 2 testing in breast cancer. $\mathbf{J}$ Clin Oncol. 2007;25:118-45.

2. WHO Classification of Tumours of the Breast. Fourth Edition - WHO - OMS - [Internet]. [cited 2018 Feb 9]. Available from:

http://apps.who.int/bookorders/WHP/detart1.jsp?sesslan=1\&codlan=1\&codcol=70\&codc $\mathrm{ch}=4004$

3. Symmans WF, Peintinger F, Hatzis C, Rajan R, Kuerer H, Valero V, et al. Measurement of residual breast cancer burden to predict survival after neoadjuvant chemotherapy. $\mathrm{J}$ Clin Oncol Off J Am Soc Clin Oncol. 2007;25:4414-22. 


\section{Supplementary Tables}

Supplementary Table S1. BRCA screened patients' characteristics among by BRCA status

\begin{tabular}{|c|c|c|c|c|c|}
\hline Characteristics & Class & Overall & BRCA mutation & BRCA wild-type & \multirow{2}{*}{$p$} \\
\hline \multicolumn{2}{|l|}{$n=$} & $267(100 \%)$ & $46(17 \%)$ & $221(83 \%)$ & \\
\hline \multicolumn{2}{|l|}{ Age (mean) } & 41.31 & 39.5 & 41.7 & 0.15 \\
\hline \multirow{2}{*}{$\begin{array}{l}\text { Menopausal } \\
\text { status }\end{array}$} & pre & $228(85.7 \%)$ & $41(89.1 \%)$ & $187(85.0 \%)$ & 0.62 \\
\hline & post & $38(14.3 \%)$ & $5(10.9 \%)$ & $33(15.0 \%)$ & \\
\hline \multicolumn{2}{|l|}{ BMI (mean) } & 23.50 & 22.8 & 23.6 & 0.24 \\
\hline \multirow[t]{4}{*}{ BMI class } & {$[15,19]$} & $23(8.6 \%)$ & $6(13.3 \%)$ & $17(7.7 \%)$ & 0.248 \\
\hline & $(19,25]$ & $178(66.9 \%)$ & $31(68.9 \%)$ & $147(66.5 \%)$ & \\
\hline & $(25,30]$ & $47(17.7 \%)$ & $4(8.9 \%)$ & $43(19.5 \%)$ & \\
\hline & $(30,50]$ & $18(6.8 \%)$ & $4(8.9 \%)$ & $14(6.3 \%)$ & \\
\hline \multirow{2}{*}{$\begin{array}{l}\text { Family history } \\
\text { of } \mathrm{BC}\end{array}$} & no & $116(43.9 \%)$ & $12(26.1 \%)$ & $104(47.7 \%)$ & 0.01 \\
\hline & yes & $148(56.1 \%)$ & $34(73.9 \%)$ & $114(52.3 \%)$ & \\
\hline \multirow[t]{3}{*}{ Clinical tumor size } & T1 & $27(10.1 \%)$ & $5(10.9 \%)$ & $22(10.0 \%)$ & 0.50 \\
\hline & T2 & $181(67.8 \%)$ & $28(60.9 \%)$ & $153(69.2 \%)$ & \\
\hline & T3 & $59(22.1 \%)$ & $13(28.3 \%)$ & $46(20.8 \%)$ & \\
\hline \multirow{2}{*}{$\begin{array}{l}\text { Clinical } \\
\text { nodal status }\end{array}$} & NO & $110(41.2 \%)$ & $17(37.0 \%)$ & $93(42.1 \%)$ & 0.63 \\
\hline & N1-N2-N3 & $157(58.8 \%)$ & $29(63.0 \%)$ & $128(57.9 \%)$ & \\
\hline \multirow[t]{2}{*}{ Histology } & NST & $256(95.9 \%)$ & 43 (93.5\%) & $213(96.4 \%)$ & $\mathrm{NaN}$ \\
\hline & others & $11(4.1 \%)$ & $3(6.5 \%)$ & $8(3.6 \%)$ & \\
\hline \multirow[t]{2}{*}{ Grade } & $1-11$ & $86(32.8 \%)$ & $10(23.3 \%)$ & $76(34.7 \%)$ & 0.24 \\
\hline & III & $176(67.2 \%)$ & $33(76.7 \%)$ & $143(65.3 \%)$ & \\
\hline \multicolumn{2}{|l|}{ Mitotic Index (mean) } & 26.57 & 30.8 & 25.6 & 0.24 \\
\hline \multirow[t]{3}{*}{ Subtype } & luminal & $90(33.7 \%)$ & $15(32.6 \%)$ & $75(33.9 \%)$ & $<0.01$ \\
\hline & TNBC & $110(41.2 \%)$ & $27(58.7 \%)$ & $83(37.6 \%)$ & \\
\hline & HER2 & $67(25.1 \%)$ & $4(8.7 \%)$ & $63(28.5 \%)$ & \\
\hline \multicolumn{2}{|l|}{ str TILs (mean) } & $20.0[10.0-40.0]$ & $20.0[13.8-40.0]$ & $20.0[10.0-40.0]$ & 0,78 \\
\hline \multicolumn{2}{|l|}{ IT TILs (mean) } & $5.0[5.0-15.0]$ & $5.0[5.0-11.3]$ & $7.5[5.0-20.0]$ & 0,72 \\
\hline \multirow[t]{4}{*}{ NAC Regimen } & $A C$ & $29(10.9 \%)$ & $4(8.7 \%)$ & $25(11.4 \%)$ & 0.49 \\
\hline & AC-Taxanes & $221(83.1 \%)$ & $41(89.1 \%)$ & $180(81.8 \%)$ & \\
\hline & Taxanes & $7(2.6 \%)$ & $1(2.2 \%)$ & $6(2.7 \%)$ & \\
\hline & Others & $9(3.4 \%)$ & $0(0.0 \%)$ & $9(4.1 \%)$ & \\
\hline \multirow[t]{2}{*}{ pCR class } & No pCR & $182(68.4 \%)$ & $25(54.3 \%)$ & $157(71.4 \%)$ & 0,04 \\
\hline & pCR & $84(31.6 \%)$ & $21(45.7 \%)$ & $63(28.6 \%)$ & \\
\hline \multirow[t]{3}{*}{ Nodal involvment } & 0 & $176(66.2 \%)$ & $35(76.1 \%)$ & $141(64.1 \%)$ & 0,16 \\
\hline & $1-3$ & $64(24.1 \%)$ & $6(13.0 \%)$ & $58(26.4 \%)$ & \\
\hline & $\geq 4$ & $26(9.8 \%)$ & $5(10.9 \%)$ & $21(9.5 \%)$ & \\
\hline \multicolumn{2}{|l|}{ str TILs (mean) } & $10.0[5.0-15.0]$ & $15.0[5.0-20.0]$ & $10.0[5.0-15.0]$ & 0,14 \\
\hline \multicolumn{2}{|l|}{ IT TILs (mean) } & $5.0[2.0-10.0]$ & $5.0[4.3-10.0]$ & $5.0[2.0-10.0]$ & 0,27 \\
\hline
\end{tabular}

Missing data: Menopausal status, $n=1$; BMI (continuous), $n=1$; BMI class, $n=1$; Family history, $n=3$; Grade, $n=5$; Mitotic index, $n=77$; Pre-NAC str TILs, $n=75$; Pre-NAC IT TILs, $n=75$; NAC regimen, $n=1 ; p C R$ status, $n=1$; Post-NAC Nodal involvment, $n=1$; Post-NAC str TILs, $n=75$; Post-NACIT TILS, $n=147$.

$\mathrm{NAC}=$ neoadjuvant chemotherapy $; \mathrm{BMI}=$ body mass index; $\mathrm{NST}=$ no special type ;NBC= triple negative breast cancer; str TILS= stromal tumor-infiltrating lymphocytes; IT TILS= intratumoral-infiltrating lymphocytes; $\mathrm{AC}=$ anthracyclines; $\mathrm{pCR}=$ Pathologic complete response.

The " $n$ " denotes the number of patients. In case of categorical variables, percentages are expressed between brackets. In case of continuous variables, mean value is reported. In case of nonnormal continuous variables, median value is reported, with interquartile range between brackets. 
Supplementary Table S2. Patients' characteristics in each tumor subtype and by BRCA status

\begin{tabular}{|c|c|c|c|c|c|c|c|c|c|c|}
\hline & & & Luminal & & & TNBC & & & HER2 & \\
\hline Characteristics & Class & BRCA mutation & BRCA wild-type & $p$ & BRCA mutation & BRCA wild-type & $p$ & BRCA mutation & BRCA wild-type & $p$ \\
\hline$n=$ & & $15(16.7 \%)$ & $75(83.3 \%)$ & & $27(24.5 \%)$ & $83(75.5 \%)$ & & $4(6.0 \%)$ & $63(94.0 \%)$ & \\
\hline Age (mean) & & 38.5 & 42.3 & 0,13 & 39.6 & 42.2 & 0,19 & 43.5 & 40.2 & 0,50 \\
\hline Menopausal & pre & $14(93.3 \%)$ & $64(86.5 \%)$ & 0,76 & $24(88.9 \%)$ & $72(86.7 \%)$ & 1,00 & $3(75.0 \%)$ & $51(81.0 \%)$ & 1,00 \\
\hline status & post & $1(6.7 \%)$ & $10(13.5 \%)$ & & $3(11.1 \%)$ & $11(13.3 \%)$ & & $1(25.0 \%)$ & $12(19.0 \%)$ & \\
\hline BMI (mean) & & 22.2 & 23.5 & 0,32 & 23.5 & 23.3 & 0,74 & 20.4 & $24.3(4.4 \%)$ & 0,09 \\
\hline BMI class & {$[15,19]$} & $4(28.6 \%)$ & $7(9.3 \%)$ & 0.204 & $1(3.7 \%)$ & $7(8.4 \%)$ & 0.251 & $1(25.0 \%)$ & $3(4.8 \%)$ & 0.298 \\
\hline & $(19,25]$ & $8(57.1 \%)$ & $49(65.3 \%)$ & & $20(74.1 \%)$ & $55(66.3 \%)$ & & $3(75.0 \%)$ & $43(68.3 \%)$ & \\
\hline & $(25,30]$ & $1(7.1 \%)$ & $14(18.7 \%)$ & & $3(11.1 \%)$ & $18(21.7 \%)$ & & $0(0.0 \%)$ & $11(17.5 \%)$ & \\
\hline & $(30,50]$ & $1(7.1 \%)$ & $5(6.7 \%)$ & & $3(11.1 \%)$ & $3(3.6 \%)$ & & $0(0.0 \%)$ & $6(9.5 \%)$ & \\
\hline Family history & no & $2(13.3 \%)$ & $26(35.1 \%)$ & 0,18 & $10(37.0 \%)$ & $46(56.1 \%)$ & 0,13 & $0(0.0 \%)$ & $32(51.6 \%)$ & 0,14 \\
\hline & yes & $13(86.7 \%)$ & $48(64.9 \%)$ & & $17(63.0 \%)$ & $36(43.9 \%)$ & & $4(100.0 \%)$ & $30(48.4 \%)$ & \\
\hline Clinical tumor size & $\mathrm{T} 1$ & $1(6.7 \%)$ & $5(6.7 \%)$ & 0,99 & $2(7.4 \%)$ & $11(13.3 \%)$ & 0,28 & $2(50.0 \%)$ & $6(9.5 \%)$ & 0,04 \\
\hline & T2 & $11(73.3 \%)$ & $54(72.0 \%)$ & & $16(59.3 \%)$ & $56(67.5 \%)$ & & $1(25.0 \%)$ & $43(68.3 \%)$ & \\
\hline & T3 & $3(20.0 \%)$ & $16(21.3 \%)$ & & $9(33.3 \%)$ & $16(19.3 \%)$ & & $1(25.0 \%)$ & $14(22.2 \%)$ & \\
\hline Clinical & NO & $5(33.3 \%)$ & $35(46.7 \%)$ & 0,51 & $10(37.0 \%)$ & $34(41.0 \%)$ & 0,89 & $2(50.0 \%)$ & $24(38.1 \%)$ & 1,00 \\
\hline nodal status & N1-N2-N3 & $10(66.7 \%)$ & $40(53.3 \%)$ & & $17(63.0 \%)$ & $49(59.0 \%)$ & & $2(50.0 \%)$ & $39(61.9 \%)$ & \\
\hline Histology & NST & $13(86.7 \%)$ & $72(96.0 \%)$ & $\mathrm{NaN}$ & $26(96.3 \%)$ & $78(94.0 \%)$ & $\mathrm{NaN}$ & $4(100.0 \%)$ & $63(100.0 \%)$ & $\mathrm{NaN}$ \\
\hline & others & $2(13.3 \%)$ & $3(4.0 \%)$ & & $1(3.7 \%)$ & $5(6.0 \%)$ & & $0(0.0 \%)$ & $0(0.0 \%)$ & \\
\hline Grade & $1-11$ & $6(42.9 \%)$ & $42(56.0 \%)$ & 0,55 & $2(8.0 \%)$ & $10(12.2 \%)$ & 0,53 & $2(50.0 \%)$ & $24(38.7 \%)$ & $\mathrm{NaN}$ \\
\hline & III & $8(57.1 \%)$ & $33(44.0 \%)$ & & $23(92.0 \%)$ & $72(87.8 \%)$ & & $2(50.0 \%)$ & $38(61.3 \%)$ & \\
\hline Mitotic Index (mean & & 23.0 & 18.5 & 0,56 & 36.3 & 31.8 & 0,46 & 13.0 & 21.5 & 0,45 \\
\hline str TILs (mean) & & $12.5[8.8-15.0]$ & $15.0[10.0-25.0]$ & 0,17 & $27.5[15.0-60.0]$ & $30.0[15.0-50.0]$ & 0,71 & $22.5[20.0-28.8]$ & $20.0[10.0-35.0]$ & 0,66 \\
\hline IT TILs (mean) & & $5.0[4.3-6.3]$ & $10.0[5.0-15.0]$ & 0,07 & $5.0[5.0-15.0]$ & $5.0[2.0-15.0]$ & 0,37 & $15.0[10.0-20.0]$ & $15.0[5.0-20.0]$ & 0,77 \\
\hline NAC Regimen & $A C$ & $3(20.0 \%)$ & $13(17.6 \%)$ & 0,83 & $1(3.7 \%)$ & $9(10.8 \%)$ & $\mathrm{NaN}$ & $0(0.0 \%)$ & $3(4.8 \%)$ & 0,77 \\
\hline & AC-Taxanes & $11(73.3 \%)$ & $58(78.4 \%)$ & & $26(96.3 \%)$ & $73(88.0 \%)$ & & $4(100.0 \%)$ & $49(77.8 \%)$ & \\
\hline & Taxanes & $1(6.7 \%)$ & $2(2.7 \%)$ & & $0(0.0 \%)$ & $0(0.0 \%)$ & & $0(0.0 \%)$ & $4(6.3 \%)$ & \\
\hline & Others & $0(0.0 \%)$ & $1(1.4 \%)$ & & $0(0.0 \%)$ & $1(1.2 \%)$ & & $0(0.0 \%)$ & $7(11.1 \%)$ & \\
\hline & & & & & & & & & & \\
\hline pCR class & No $\mathrm{pCR}$ & $10(66.7 \%)$ & $70(94.6 \%)$ & $<0,01$ & $14(51.9 \%)$ & $47(56.6 \%)$ & 0,83 & $1(25.0 \%)$ & $40(63.5 \%)$ & 0,32 \\
\hline & pCR & $5(33.3 \%)$ & $4(5.4 \%)$ & & $13(48.1 \%)$ & $36(43.4 \%)$ & & $3(75.0 \%)$ & $23(36.5 \%)$ & \\
\hline Nodal involvment & 0 & $8(53.3 \%)$ & $30(40.5 \%)$ & 0,23 & $23(85.2 \%)$ & $65(78.3 \%)$ & 0,74 & $4(100.0 \%)$ & $46(73.0 \%)$ & 0,49 \\
\hline & $1-3$ & $3(20.0 \%)$ & $32(43.2 \%)$ & & $3(11.1 \%)$ & $13(15.7 \%)$ & & $0(0.0 \%)$ & $13(20.6 \%)$ & \\
\hline & $\geq 4$ & $4(26.7 \%)$ & $12(16.2 \%)$ & & $1(3.7 \%)$ & $5(6.0 \%)$ & & $0(0.0 \%)$ & $4(6.3 \%)$ & \\
\hline Str TILs (mean) & & $15.0[13.8-20.0]$ & $10.0[5.0-10.0]$ & $<0,01$ & $10.0[5.0-20.0]$ & $10.0[5.0-25.0]$ & 0,82 & $10.0[4.3-15.0]$ & $10.0[5.0-12.5]$ & 0,95 \\
\hline IT TILs (mean) & & $10.0[5.0-12.5]$ & $5.0[3.0-5.0]$ & 0,02 & $5.0[1.8-6.3]$ & $5.0[3.0-10.0]$ & 0,54 & $5.0[5.0-5.0]$ & $5.0[2.0-5.0]$ & 0,68 \\
\hline
\end{tabular}

Mis sing data: Menopausal status, $n=1$; BMI (continuous), $n=1$; BMI class, $n=1$; Family history, $n=3$; Grade, $n=5$; Mitotic index, $n=77$; Pre-NAC str TILs, $n=75$; Pre-NAC IT TILs, $n=75 ;$ NAC regimen, $n=1 ; p C R$ sta tus, $n=1$; Post-NAC Nodal involvment, $n=1$; Post-NAC str TILs, n=75; Post-NACIT TILS, $n=147$.

NAC=neoadjuvant chemotherapy ; BMI=body mass index; NST= no special type ; TNBC= triple negative breast cancer; str TILs= stromal tumor-infiltrating lymphocytes ; IT TILs= intratumoral-infiltrating lymphocytes; $A C=$ anthracyclines; $\mathrm{pCR}=$ Pathologic complete response.

The " $\mathrm{n}$ " denotes the number of patients. In case of categorical variables, percentages are expressed between brackets. In case of continuous variables, mean value is reported. In case of nonnormal continuous variables, median value is reported, with interquartile range between brackets. 
Supplementary Table S3. Association of BRCA status with pCR after univariate and multivariate analysis in the whole population

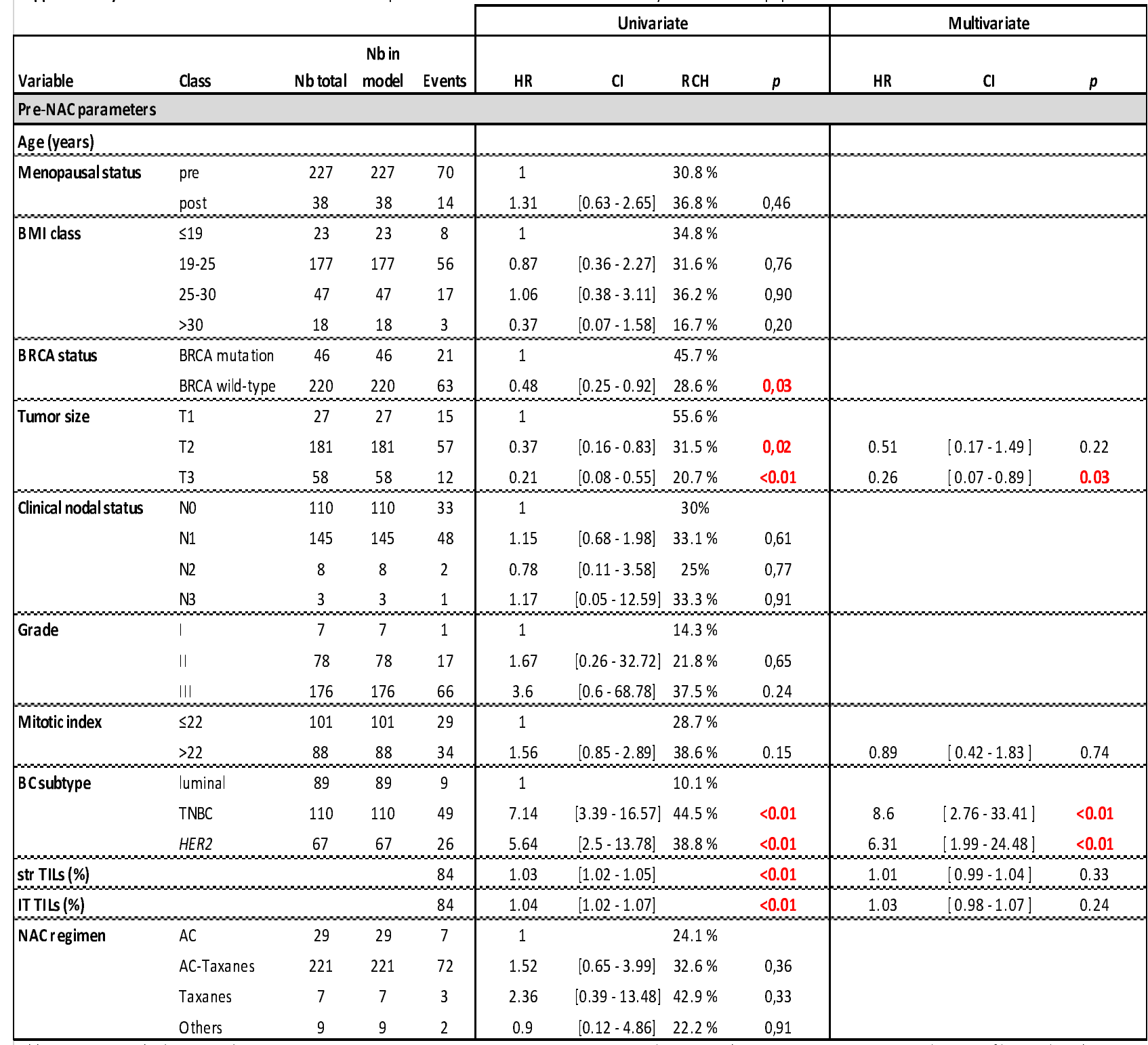

Abbreviation, $\mathrm{BMI}=$ body mass index; ER=oestrogen receptor; PR=progesterone receptor; TNBC= triple negative breast cancer; str TILs= stromal tumor-infiltrating lymphocytes ;

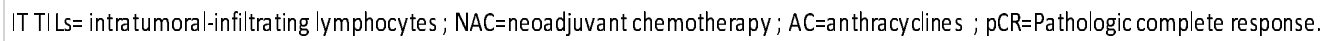




\section{Supplementary Figures}

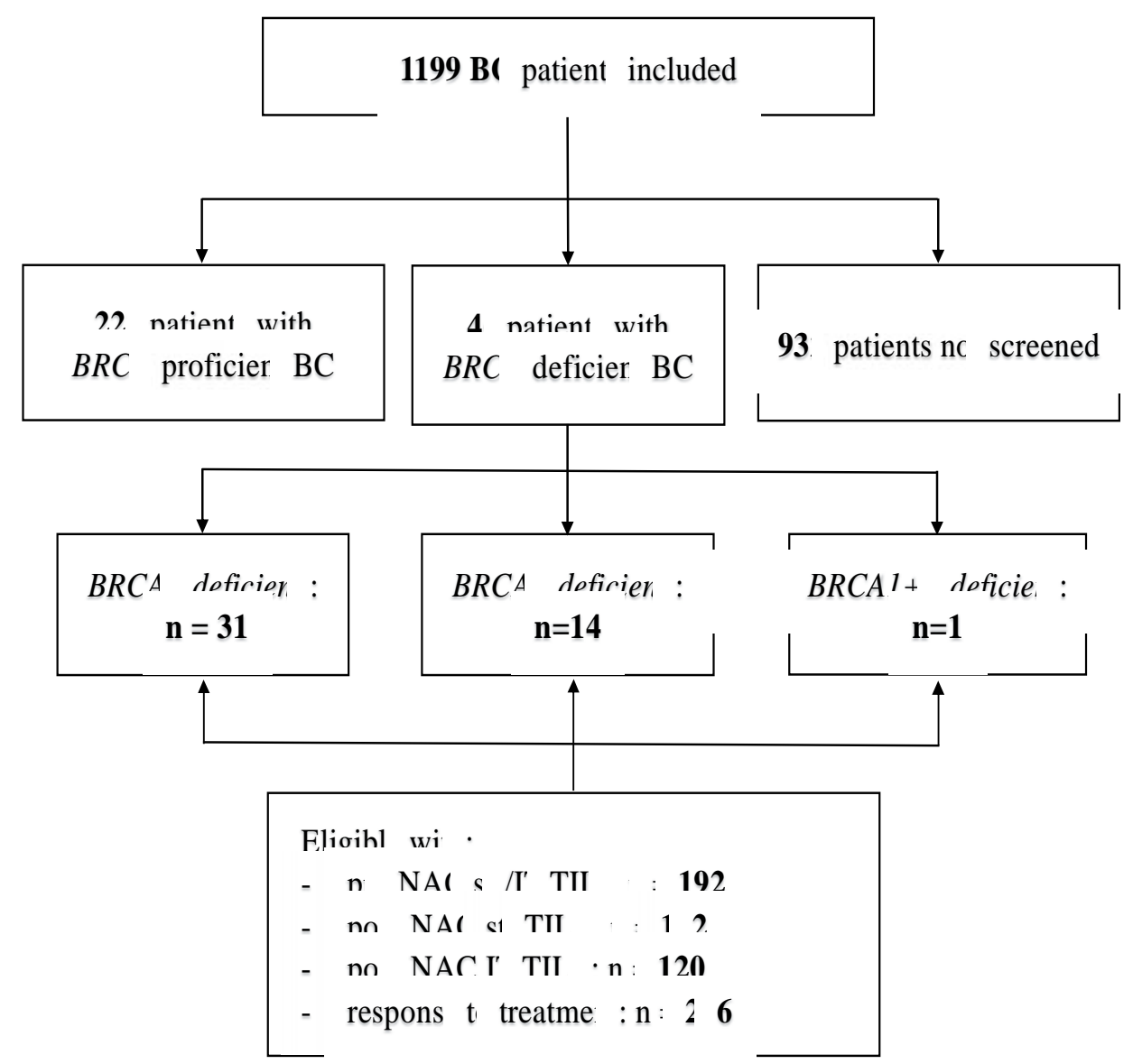

Supplementary Figure S 1. Study flow diagram of included patients and tumors samples available 


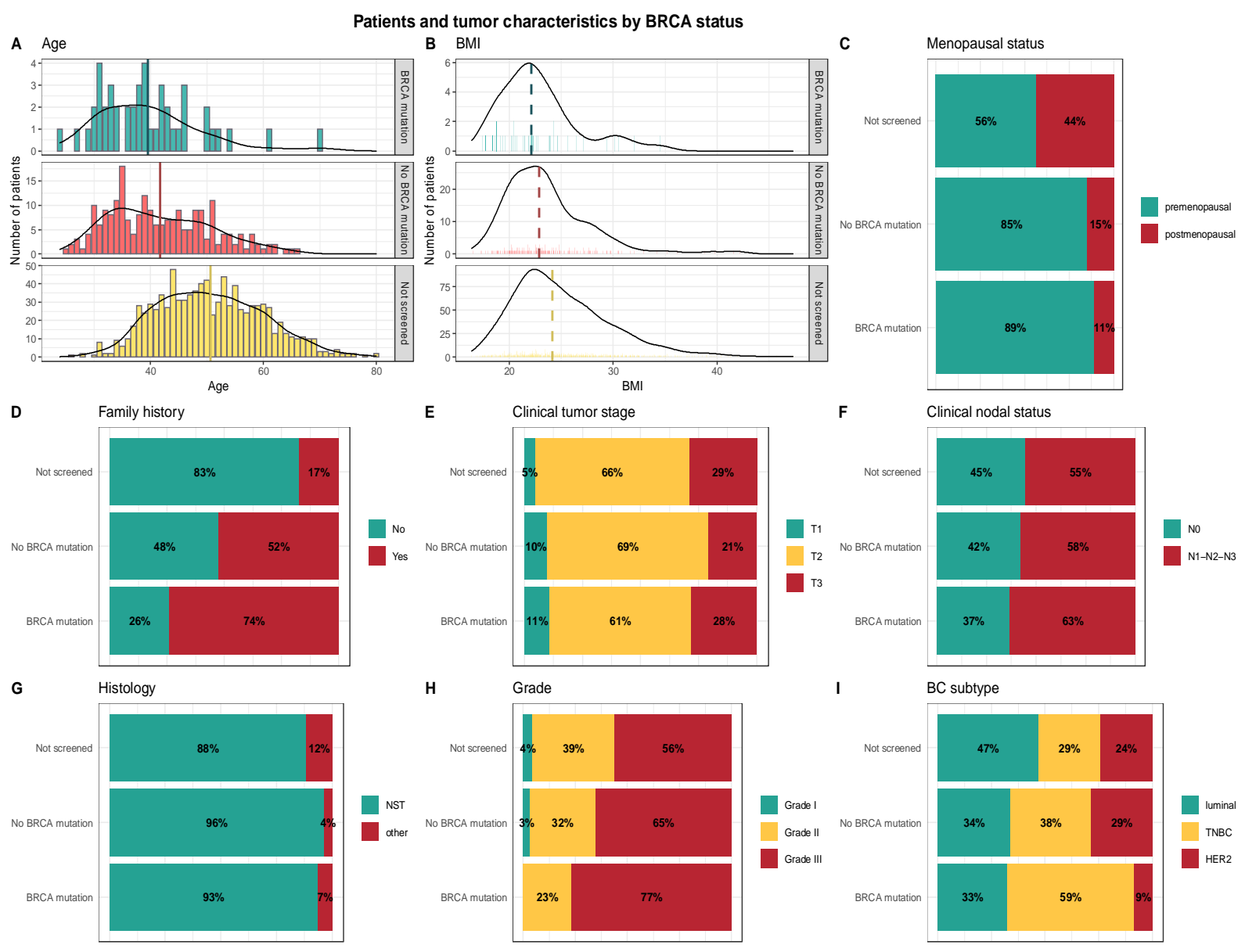

Supplementary Figure S 2. Patients' and tumors 'characteristics by BRCA status. (All $(n=1199)$, BRCA mutation ( $n=36)$, BRCA wildtype( $n=156)$, not screened ( $n=1007$ ). A, Age (kernel density plot). B, BMI (kernel density plot). C, Menopausal status (barplot). D, Family history (barplot). E, Clinical tumor stage (barplot). F, Clinical nodal status (barplot). G, Histology (barplot). H, Grade (barplot). I, BC subtype (barplot).

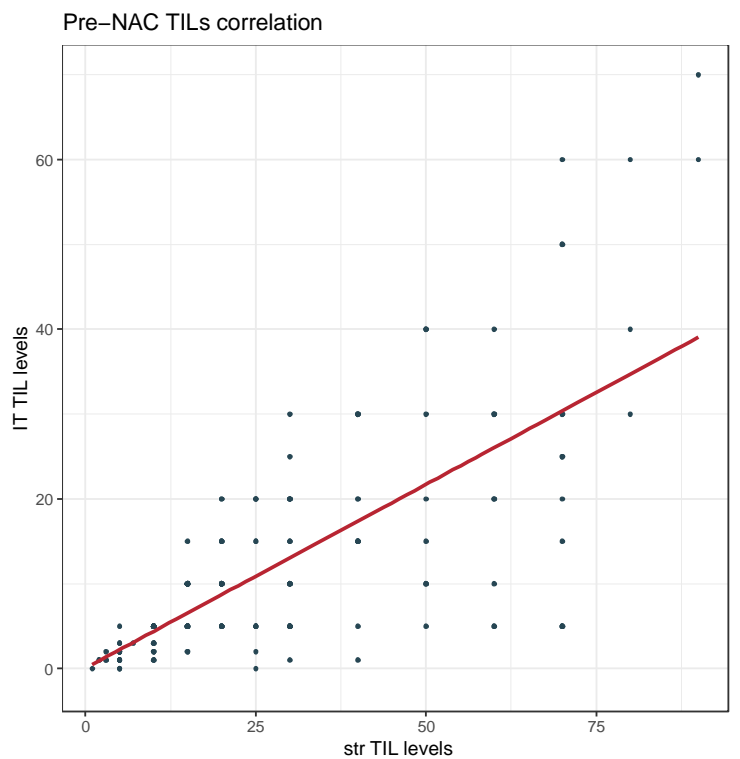

Supplementary Figure S 3. Variation of pre-NAC str TIL levels according to the pre-NAC IT TIL levels (scatterplot) (str TILs ( $\mathrm{n}=192$ ), IT TILs $(n=192))$. 


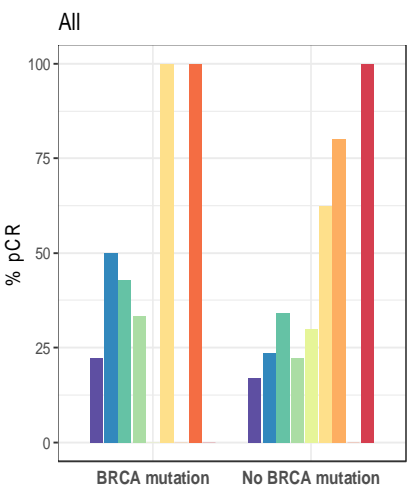

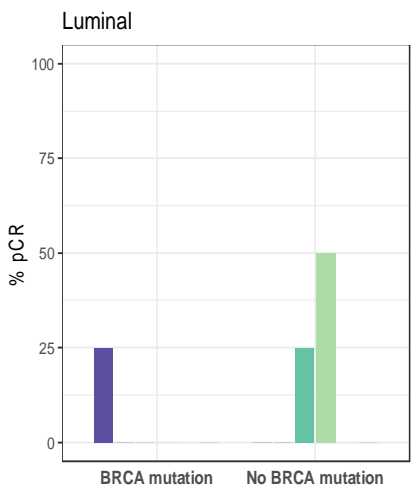

C

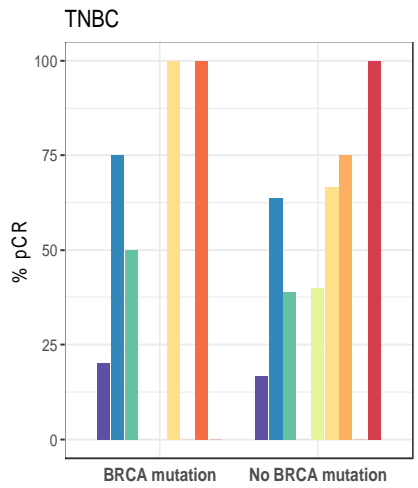

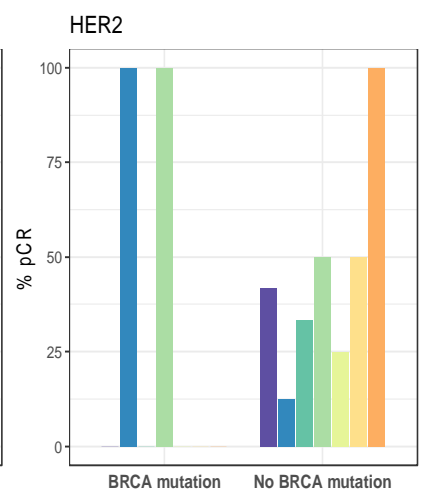

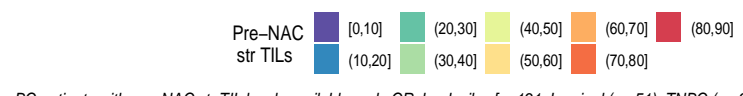

$B C$ patients with pre-NAC str TIL levels available and $p C R$, by deciles [ $n=191$; Luminal ( $n=51)$, TNBC ( $(n=97)$ and HER2-positive $(n=43)$

Supplementary Figure S 4. pCR rate by pre-NAC str TIL levels by BRCA status (TILs were binned by increments of $10 \%$ ). A, whole population ( $n=191$, BRCA mutation ( $n=36)$, BRCA wild-type $(n=155))$. B, luminal tumors ( $n=51, B R C A$ mutation( $n=8)$, BRCA wildtype $(n=43))$. C, TNBC ( $n=97)$, BRCA mutation( $n=24)$, BRCA wild-type( $n=73))$. D, HER2-positive BC ( $n=43, B R C A$ mutation( $n=4)$, BRCA wild-type $(n=39))$.

A

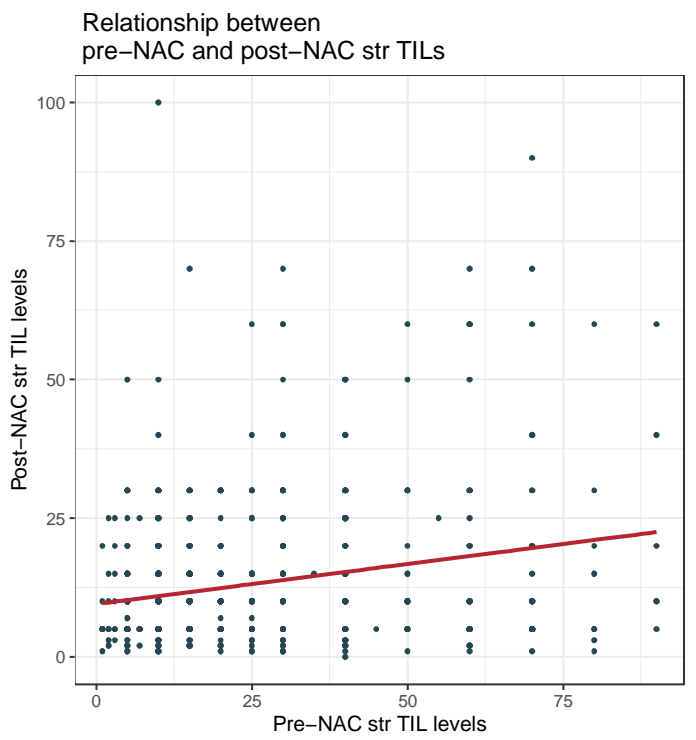

B

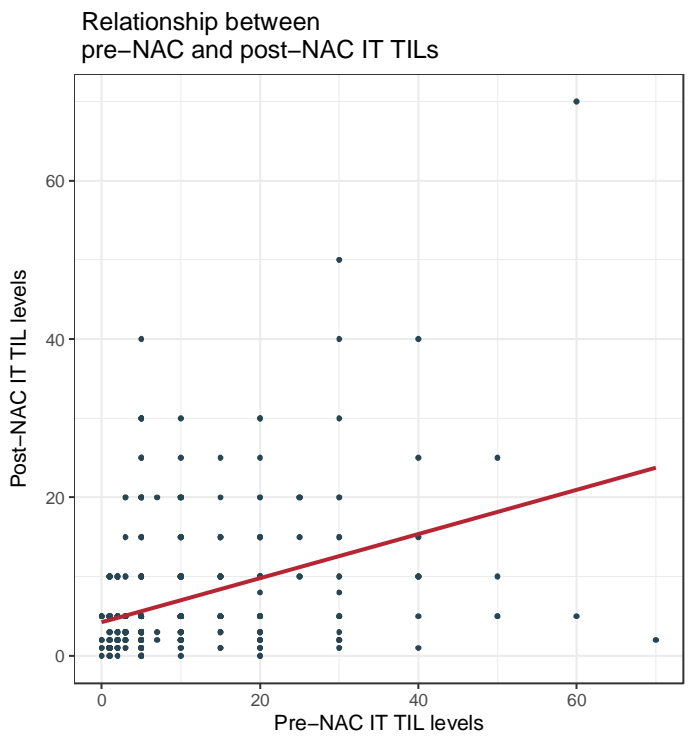

Supplementary Figure S 5. TILs correlation between pre and post-NAC. A, Variation of post-NAC str TIL levels according to the preNAC str TIL levels (scatterplot) (pre-NAC str TILs ( $n=192)$, post-NAC str TILs ( $n=192)$ ). B, Variation of post-NAC IT TIL levels according to the pre-NAC IT TIL levels (scatterplot) (pre-NAC IT TILs ( $n=192)$, post-NAC IT TILs ( $n=120)$ ). 
A

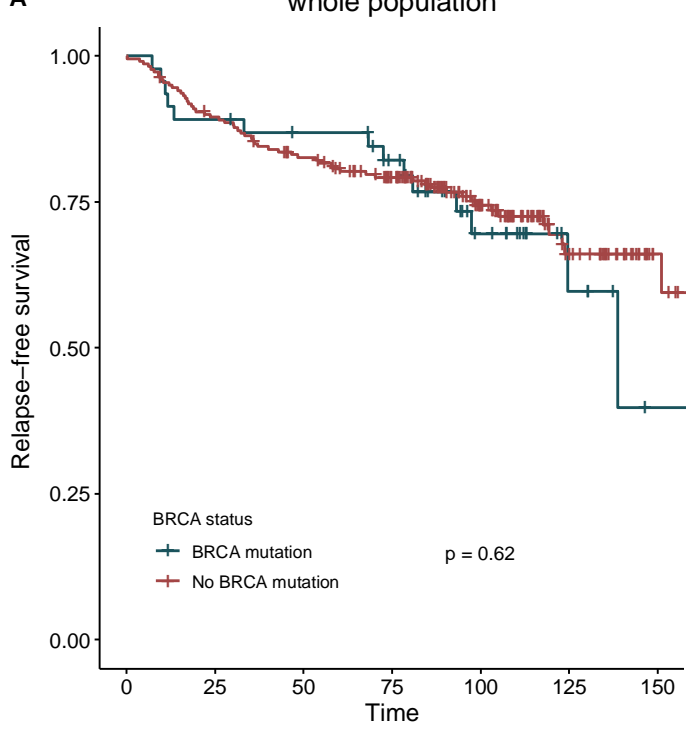

number at risk
B

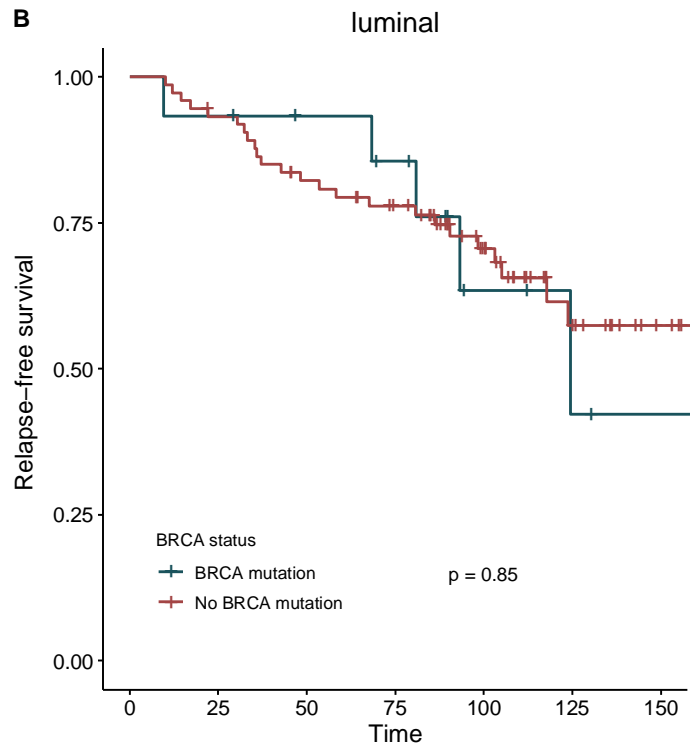

number at risk

$\begin{array}{ccccccccccccccc}-46 & 41 & 38 & 32 & 17 & 6 & 1 & -15 & 14 & 12 & 10 & 4 & 2 & 1 \\ -220 & 195 & 175 & 151 & 89 & 37 & 10 & - & 74 & 68 & 58 & 51 & 32 & 13 & 4\end{array}$

C

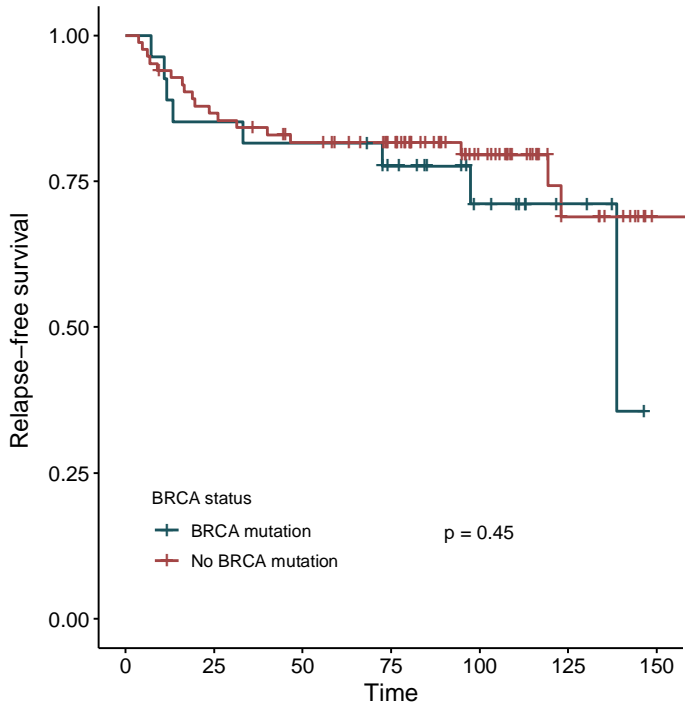

D

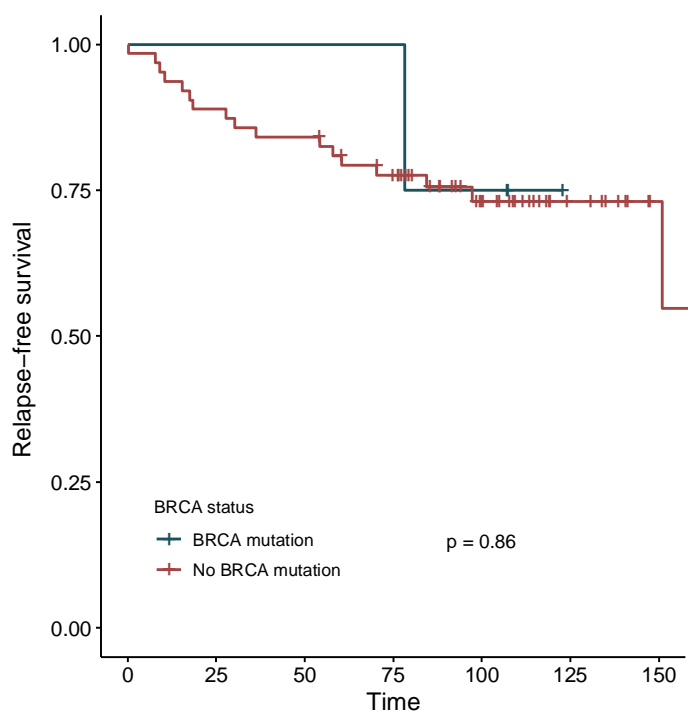

number at risk

number at risk

$\begin{array}{ccccccccccccccc}-27 & 23 & 22 & 18 & 10 & 4 & 0 & - & 4 & 4 & 4 & 4 & 3 & 0 & 0 \\ -83 & 71 & 64 & 55 & 31 & 12 & 2 & - & 63 & 56 & 53 & 45 & 26 & 12 & 4\end{array}$

Supplementary Figure $S 6$. Relapse free survival curves according BRCA status. A, whole population ( $n=267$, BRCA mutation ( $n=46$ ), BRCA wild-type $(n=220)$ ). B, luminal tumors ( $n=89$, BRCA mutation( $n=15)$, BRCA wild-type( $n=74))$. C, TNBC ( $n=110$, BRCA mutation(n=27), BRCA wild-type(n=83)). D, HER2-positive BC ( $n=67)$, BRCA mutation(n=4), BRCA wild-type(n=63)). 
A

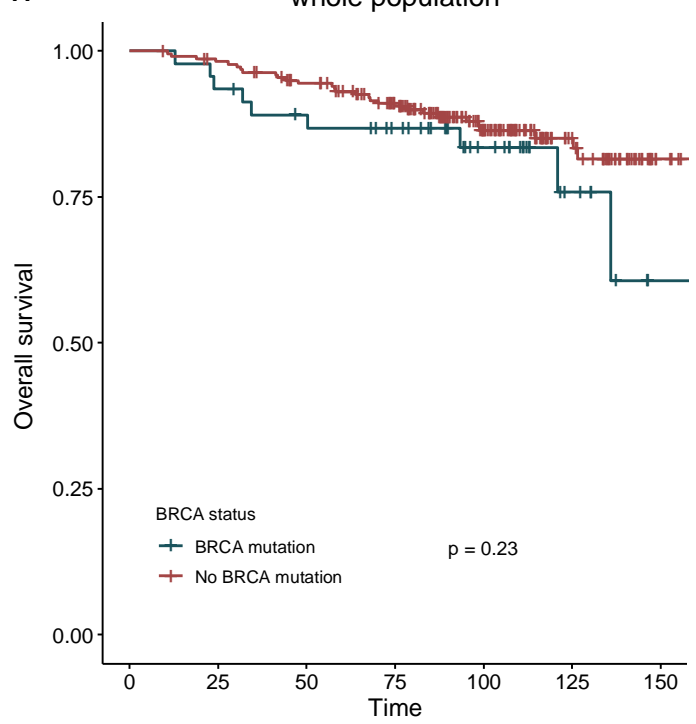

B

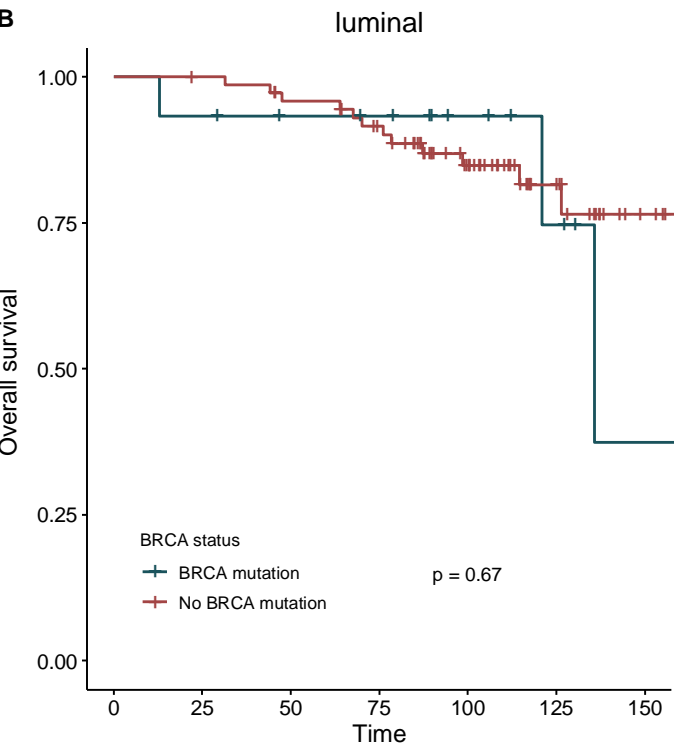

number at risk

$\begin{array}{cccccccccccccccc}- & 46 & 43 & 39 & 34 & 21 & 8 & 1 & - & 15 & 14 & 12 & 11 & 7 & 4 & 1 \\ -220 & 213 & 198 & 171 & 104 & 48 & 14 & - & 74 & 73 & 68 & 61 & 40 & 18 & 5\end{array}$

C

TNBC

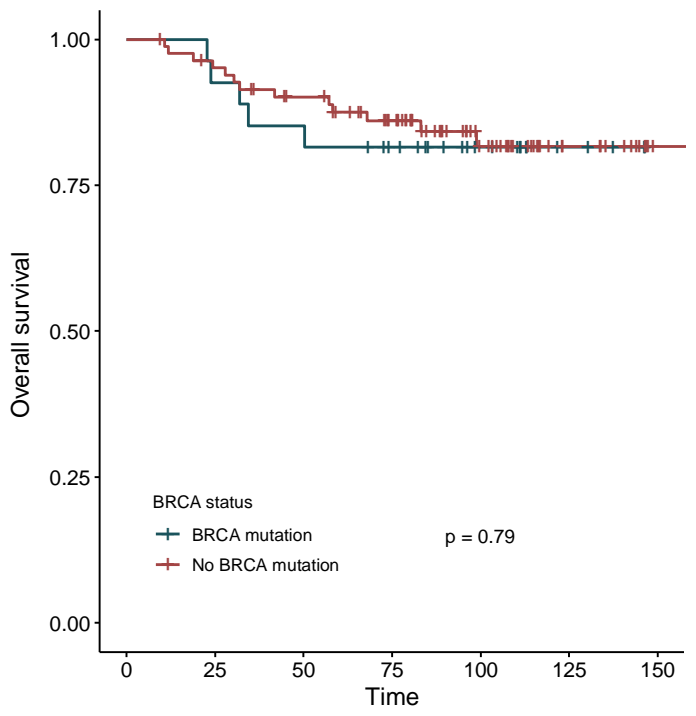

D $\quad$ HER2

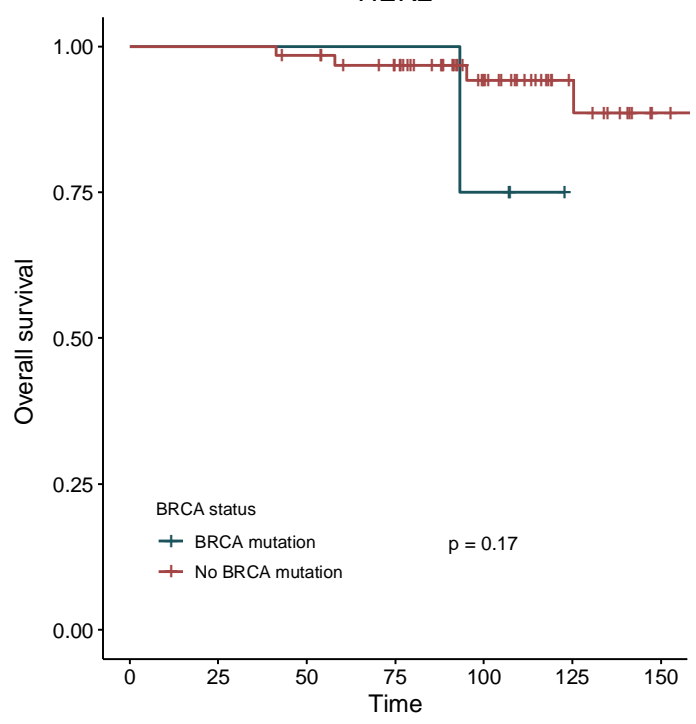

number at risk

$\begin{array}{cccccccccccccccc}-27 & 25 & 23 & 19 & 11 & 4 & 0 & - & 4 & 4 & 4 & 4 & 3 & 0 & 0 \\ -83 & 77 & 69 & 56 & 31 & 13 & 2 & - & 63 & 63 & 61 & 54 & 33 & 17 & 7\end{array}$

Supplementary Figure S 7. Overall survival curves according BRCA status. A, whole population ( $n=267$, BRCA mutation ( $n=46$ ), BRCA wild-type $(n=220)$ ). B, luminal tumors $(n=89$, BRCA mutation $(n=15)$, BRCA wild-type( $n=74)$ ). C, TNBC ( $n=110$, BRCA mutation(n=27), BRCA wild-type(n=83)). D, HER2-positive BC ( $n=67)$, BRCA mutation(n=4), BRCA wild-type(n=63)). 